\title{
Corn processing and crude protein content in calf starter: Effects on growth performance, ruminal fermentation, and blood metabolites
}

\author{
H. Makizadeh, ${ }^{1}$ M. Kazemi-Bonchenari, ${ }^{2 *}$ H. Mansoori-Yarahmadi, ${ }^{1}$ J. Fakhraei, ${ }^{1}$ H. Khanaki, ${ }^{3}$ J. K. Drackley, ${ }^{4}$ \\ and M. H. Ghaffari ${ }^{5 *}$ \\ ${ }^{1}$ Department of Animal Science, Arak Branch, Islamic Azad University, Arak, 38361-1-9131, Iran \\ ${ }^{2}$ Department of Animal Science, Faculty of Agriculture and Natural Resources, Arak University, Arak, 38156-8-8349, Iran \\ ${ }^{3}$ Faculty of Veterinary and Agricultural Sciences, Dookie Campus, The University of Melbourne, Victoria 3647, Australia \\ ${ }^{4}$ Department of Animal Sciences, University of Illinois, Urbana 61801 \\ ${ }^{5}$ Institute of Animal Science, Physiology and Hygiene Unit, University of Bonn, 53111 Bonn, Germany
}

\begin{abstract}
This study aimed to investigate the effects of feeding dairy calves starter diets containing corn grain processed by different methods (ground versus steam-flaked; GRC vs. SFC) and either $18 \%$ or $21 \%$ crude protein (CP) contents (dry matter basis) on growth performance, digestibility, ruminal fermentation, urinary purine derivatives, and blood metabolites of dairy calves. Holstein dairy calves $(39.3 \pm 1.9 \mathrm{~kg}$ of body weight, $\mathrm{n}=$ 12 calves per treatment, 6 males and 6 females) were randomly distributed to experimental diets in a $2 \times$ 2 factorial arrangement of treatments. The 4 dietary treatments were (1) starter diet containing GRC and $18 \%$ dietary CP (GRC-18CP; geometric mean particle size, GMPS $=0.73 \mathrm{~mm}) ;(2)$ GRC and $21 \%$ dietary $\mathrm{CP}$ $($ GRC-21CP; GMPS $=0.71 \mathrm{~mm}) ;(3) \mathrm{SFC}$ and $18 \%$ dietary $\mathrm{CP}$ (SFC-18CP; GMPS $=2.21 \mathrm{~mm}$ ); and $(4)$ SFC and $21 \%$ dietary CP (SFC-21CP; GMPS $=2.16$ $\mathrm{mm})$. Calves were weaned on $\mathrm{d} 63$ and remained in the study until d 83 of age. The starter feed intake did not differ among treatments; however, average daily gain and feed efficiency (FE) were improved and final body weight was higher for SFC diets compared with GRC diets. The organic matter and nonfiber carbohydrate digestibilities were greater for calves fed the SFC diets than for those fed the GRC diets. The ruminal total volatile fatty acid concentrations and the molar proportions of propionate and butyrate were greater, and the molar proportion of acetate and $\mathrm{NH}_{3}-\mathrm{N}$ concentrations were lower, for calves fed the SFC diets than for those fed the GRC diets. The excretion of allantoin and total purine derivatives, and subsequently microbial protein synthesis, were greater for calves fed the SFC diets
\end{abstract}

\footnotetext{
Received March 23, 2020.

Accepted May 8, 2020.

*Corresponding authors: m-kazemibonchenari@araku.ac.ir and morteza1@uni-bonn.de
}

than the GRC diets. The total urinary nitrogen excretion and its proportion of $\mathrm{N}$ intake were lower for calves fed the SFC diets than the GRC diets. The blood concentrations of insulin (pre- and postweaning), glucose (postweaning), and $\beta$-hydroxybutyrate (preweaning) were greater and blood urea nitrogen (preweaning) was lower for calves fed the SFC diets than the GRC diets. The protein content of the concentrate did not affect feed intake, growth performance, or ruminal fermentation of the calves. The neutral detergent fiber digestibility was greater for calves fed the $21 \% \mathrm{CP}$ diets than the $18 \%$ CP diets. No interaction between main effects was observed regarding the starter intake, average daily gain, body weight, FE, ruminal fermentation, and nutrient digestibility of calves. The interaction between corn grain processing and starter protein content was significant for withers and hip heights with the greatest values found for SFC-21CP treatment. Our results show that steam flaking of corn improved the organic matter and nonfiber carbohydrate digestibilities, weight gain, $\mathrm{FE}$, and ruminal microbial protein synthesis, and reduced urinary nitrogen excretion compared with grinding corn. Regardless of the marginal benefit derived from feeding the diet containing SFC and $21 \% \mathrm{CP}$ in the height of calves, lower starter protein content $(18 \%$ CP) may be used efficiently when calves are fed the SFC diets.

Key words: dairy calf, corn processing, crude protein, microbial protein synthesis, nitrogen efficiency

\section{INTRODUCTION}

A successful calf rearing program aims to maximize the growth potential of dairy calves early in life. Readily fermentable carbohydrates and processing of grains play an important role in encouraging early starter feed intake and promoting excellent growth (Bateman et al., 2009; Omidi-Mirzaei et al., 2018). Corn grain ferments 
more slowly than barley or wheat, and slower rates of ruminal digestion increase the quantity of starch bypassing the reticulorumen (Khan et al., 2007). Increased starch leaving the rumen may pose a problem for small intestinal starch digestibility due to low pancreatic $\alpha$-amylase production during the preweaning period (Dennis et al., 2017). An increased surface area of grains allows better contact with digestive enzymes in the rumen and can improve starch digestibility (Huntington, 1997; Owens et al., 1997).

However, excessive grain processing negatively influenced digestibility and performance in calves (Gimeno et al., 2015; Kazemi-Bonchenari et al., 2017). Bateman et al. (2009) indicated that calves fed starters manufactured with large amounts of fines had less feed intake and slower ADG than calves fed a textured starter. Recently, Aragona et al. (2020) reported that highstarch $(51 \%)$, low-fiber textured starters in dairy calves supported more ADG and more hip width change than low-starch (11\%), high-fiber pelleted starters. Furthermore, Omidi-Mirzaei et al. (2018) stated that reducing the number of fine particles in the starter diet can improve growth performance in dairy calves. Regardless of the particle size (PS) of processed grains, ruminal starch availability is highest in steam-flaked grains, followed by finely ground grains, then dry-rolled grains, and is lowest in whole grains (Huntington, 1997).

Steam flaking of corn improves ruminal and totaltract starch digestion as well as ruminal $\mathrm{N}$ efficiency and postruminal $\mathrm{N}$ digestion compared with dry processing such as dry rolling and grinding (Zinn et al., 1998). As reviewed by Theurer et al. (1999), steam flaking increases surface area and allows for greater microbial attachment and digestion of the starch granules, which consequently increases energy and microbial protein availability. Endosperm texture, starch granule structure, and granule shape, as well as the coverage and linkages of starch with protein or lipid components in seed grains, influence the site and extent of starch digestion (Philippeau et al., 1999; Svihus et al., 2005). Mojahedi et al. (2018) reported that dairy calves fed steam-flaked corn grain (SFC) had greater ADG compared with cracked corn when calves received alfalfa hay. Despite different processing effects on carbohydrate fermentability, the geometric mean particle size (GMPS) also could influence the response of calves. For instance, the GMPS was 2.13, 1.58, and $0.74 \mathrm{~mm}$ for SFC, cracked corn grain, and ground corn grain, respectively (Gimeno et al., 2015; Mojahedi et al., 2018). Recently it has been determined in dairy cows that feeding GRC versus SFC with different GMPS influenced performance (Ahmadi et al., 2020); however, feeding GRC versus SFC with different GMPS has not been documented in preweaning dairy calves.
In addition to ruminal starch availability, adequate $\mathrm{N}$ availability also is needed to optimize ruminal fermentation (Casper et al., 1999). The NRC (2001) recommended $18 \% \mathrm{CP}$ on a DM basis for conventionally reared calves. The NRC model indicates that $18 \%$ CP (DM basis) in starter also should be adequate for calves fed enhanced milk replacer. Feeding different ranges of protein content in starter diets has resulted in different recommended amounts in dairy calves $(18 \%$, Luchini et al., 1991; 19.6\%, Akayezu et al., 1994; 18\%, Hill et al., 2007). Carbohydrate sources (mainly starch) could have a substantial role in the response of calves to starter N content (Maiga et al., 1994; Abdelgadir et al., 1996). Abdelgadir et al. (1996) reported that calf performance was dependent on the source of starch used when roasted corn (contained slightly gelatinized starch) or conglomerated corn (with highly gelatinized starch) were fed to calves along with different ruminal $\mathrm{N}$ availability rates. Recently, the interaction between corn grain processing method and dietary protein content has been well documented in dairy cows (RafieeYarandi et al., 2019). Many studies have evaluated starter diets containing steam-flaked grains for dairy calves (Mirzaei et al., 2016; Dennis et al., 2017; Mojahedi et al., 2018; Quigley et al., 2018; Aragona et al., 2020) in which the starter protein content was constant across experimental treatments in each study. Moreover, most of the above-mentioned studies incorporated SFC grain in a textured starter diet, and its incorporation in a meal starter diet needs to be evaluated.

Furthermore, the combined effects of different corn processing methods and the protein content of starter diets on calf performance and nutrient digestibility have not been investigated. We tested the hypothesis of whether calves fed different ruminal starch availabilities from SFC versus GRC responded differently depending on $\mathrm{N}$ availability in the starter diet. Thus, the objective of our study was to investigate the interactive effects of 2 different processing methods of corn grain (grinding or steam flaking) with 2 different protein contents $(18 \%$ vs. $21 \% \mathrm{CP}, \mathrm{DM}$ basis) in the starter diet on growth performance, nutrient digestibility, ruminal fermentation, microbial protein synthesis (MPS), urinary $\mathrm{N}$ (UN), and blood metabolites in Holstein dairy calves.

\section{MATERIALS AND METHODS}

\section{Animals, Treatments, and Management}

The present study was conducted at a commercial dairy farm (Zarrin-Khoosheh Dairy Farm) in Arak, Iran. All animal procedures were approved by the Animal Care and Use Committee of Arak University (IACUC protocol \#IR2018011) as outlined by the Iranian 
Council of Animal Care (1995). Holstein dairy calves (n $=48 ; 39.3 \pm 1.9 \mathrm{~kg}$ of $\mathrm{BW}, \mathrm{n}=12$ calves per treatment with 6 males and 6 females) were distributed randomly to experimental diets in a $2 \times 2$ factorial arrangement of treatments. Thus, we evaluated 4 treatments: (1) starter diet containing GRC with $18 \%$ dietary CP (GRC-18CP; GMPS \pm geometric $\mathrm{SD}=0.73 \pm 0.1$ $\mathrm{mm})$; (2) starter diet containing GRC with $21 \% \mathrm{CP}$ (GRC-21CP; GMPS $=0.71 \pm 0.1 \mathrm{~mm}) ;(3)$ starter diet containing SFC with 18\% CP (SFC-18CP; GMPS $=2.21 \pm 0.4 \mathrm{~mm}$ ); and (4) starter diet containing SFC with $21 \%$ CP (SFC-21CP; GMPS $=2.16 \pm 0.3 \mathrm{~mm}$ ). Immediately after birth, calves were separated from their dams, weighed, and moved to individual pens (1.2 $\times 2.5 \mathrm{~m}$ ) bedded with sand, which was renewed every $24 \mathrm{~h}$. The calves were fed $5 \mathrm{~L}$ of colostrum during the first $12 \mathrm{~h}$ of life $(2.5 \mathrm{~L}$ by $1 \mathrm{~h}$ after birth and $2.5 \mathrm{~L}$ at $12 \mathrm{~h}$ after the first feeding). The quality of colostrum was measured with a digital Brix refractometer (PAL1, Atago Co. Ltd., Bellevue, WA) and was discarded if it measured less than 22 on the Brix scale. Frozenthawed colostrum with sufficient quality was fed to the calf if the dam produced colostrum of insufficient quantity or quality. From the second feeding time, all calves received transition milk. From d 3 to 10, calves received $4 \mathrm{~L} / \mathrm{d}$ whole milk in galvanized buckets twice daily at 0900 and $1800 \mathrm{~h}$ and $7 \mathrm{~L} / \mathrm{d}$ from d 11 to 53 of the study, followed by $3 \mathrm{~L} / \mathrm{d}$ from $\mathrm{d} 54$ to weaning at $\mathrm{d}$ 63 of the study.

Whole milk samples were obtained weekly and analyzed for fat, CP, lactose, and TS using an infrared spectrophotometer (Foss milk-o-scan, Foss Electric, Hillerød, Denmark). The average composition of offered milk was $3.17 \pm 0.09 \%$ fat, $3.04 \pm 0.07 \% \mathrm{CP}, 4.81 \pm$ $0.05 \%$ lactose, and $11.8 \%$ TS. Calves were weaned on d 63 and remained in the study until d 83 of age. Experimental diets were formulated to meet the current NRC (2001) protein requirement equal to $18 \%$ (DM basis) or at a higher amount equal to $21 \%$ (DM basis), each with either GRC or SFC. Diets were formulated to be iso-energetic but to be different in $\mathrm{CP}$ content.

Ingredients, chemical composition, and PS distribution of diets are presented in Table 1. The GRC and SFC diets were prepared from the same batch of corn grain to prevent corn variety effects on results. The GRC was prepared by passing dry corn through a hammer mill with a screen size of $5 \mathrm{~mm}$ (model 5543 GEN, Isfahan Dasht, Isfahan, Iran). The SFC was prepared using a flaker (Lantus, C22129091, Chavdaneh, Isfahan, Iran) according to the method described by Plascencia and Zinn (1996). Previous literature (Savari et al., 2018) reviewed that the optimal flake density should range from 320 to $390 \mathrm{~g} / \mathrm{L}$. Thus, the roller tension and distance were adjusted to produce a flake density equal to $390 \mathrm{~g} / \mathrm{L}$ as measured after rolling but before cooling as explained previously for dairy calves (Mojahedi et al., 2018).

Starter feed was offered for ad libitum intake to permit at least $10 \%$ orts during a 24 -h period. The calves had free access to water throughout the experiment. Calf health was checked daily by a veterinarian blinded to the treatments and sick calves were treated accordingly.

\section{Sampling and Laboratory Analyses}

Starter feed refusals were collected and recorded daily at $0730 \mathrm{~h}$ and fresh starter feed was fed at $0800 \mathrm{~h}$. Body weight was recorded using an electronic balance every $10 \mathrm{~d}$, which was calibrated before initiation of the study and every month thereafter. Calves were weighed before the morning meal to eliminate the effects of gastrointestinal tract fill on BW. Average daily gain $(\mathrm{kg}$ of BW/d) was calculated as the difference between BW taken every $10 \mathrm{~d}$ divided by 10 . Feed efficiency $(\mathbf{F E})$ was computed as grams of ADG/kilogram of total DMI (liquid feed + starter feed). Diet PS distribution and their GMPS were measured using dry sieves (ASAE, $1995)$ of the following screen sizes: $4.75,2.36,1.18,0.6$, 0.3 , and $0.15 \mathrm{~mm}$. At $10-\mathrm{d}$ intervals $(\mathrm{n}=8)$, samples from feeds and orts were dried in a convection oven $\left(60^{\circ} \mathrm{C}\right.$ for $\left.48 \mathrm{~h}\right)$. Subsamples of dried feeds and orts were mixed thoroughly, ground to pass a $1-\mathrm{mm}$ screen in a mill (Ogaw Seiki Co. Ltd., Tokyo, Japan), and stored at $-20^{\circ} \mathrm{C}$ until chemical analysis. Diet samples were analyzed for CP (method 988.05; AOAC International, 2002), ether extract (method 920.39; AOAC International, 2002), and NDF without sodium sulfite, but with the inclusion of $\alpha$-amylase as adopted by Van Soest et al. (1991). The NFC component was computed as $100-(\mathrm{CP}+\mathrm{NDF}+$ ether extract + ash $)(\mathrm{NRC}$, 2001).

Feces were scored daily in the morning before the morning milk feeding using a 1 to 5 scale (score 1 being normal and 5 being watery) while calves were in individual pens (Heinrichs et al., 2003).

During the last $5 \mathrm{~d}$ of the experiment, fecal samples were collected via rectal palpation by hand at 6 and 18 $\mathrm{h}$ after the morning meal (10 samples for each animal). Fecal samples were dried in a forced-air oven $\left(60^{\circ} \mathrm{C}\right.$; $72 \mathrm{~h}$ ) and then ground in a Wiley mill (Ogaw Seiki Co., Ltd.) through a 1-mm screen. Aliquots of all fecal samples collected for each calf were mixed to obtain one composite sample for each animal. These composite fecal samples were analyzed for total N, ether extract, ash, and NDF. Apparent total-tract digestibility of nutrients (OM, NDF, CP, and ether extract) was measured by using acid insoluble ash as an internal marker 
Table 1. Ingredients, chemical composition, and particle size distribution of experimental starter diets

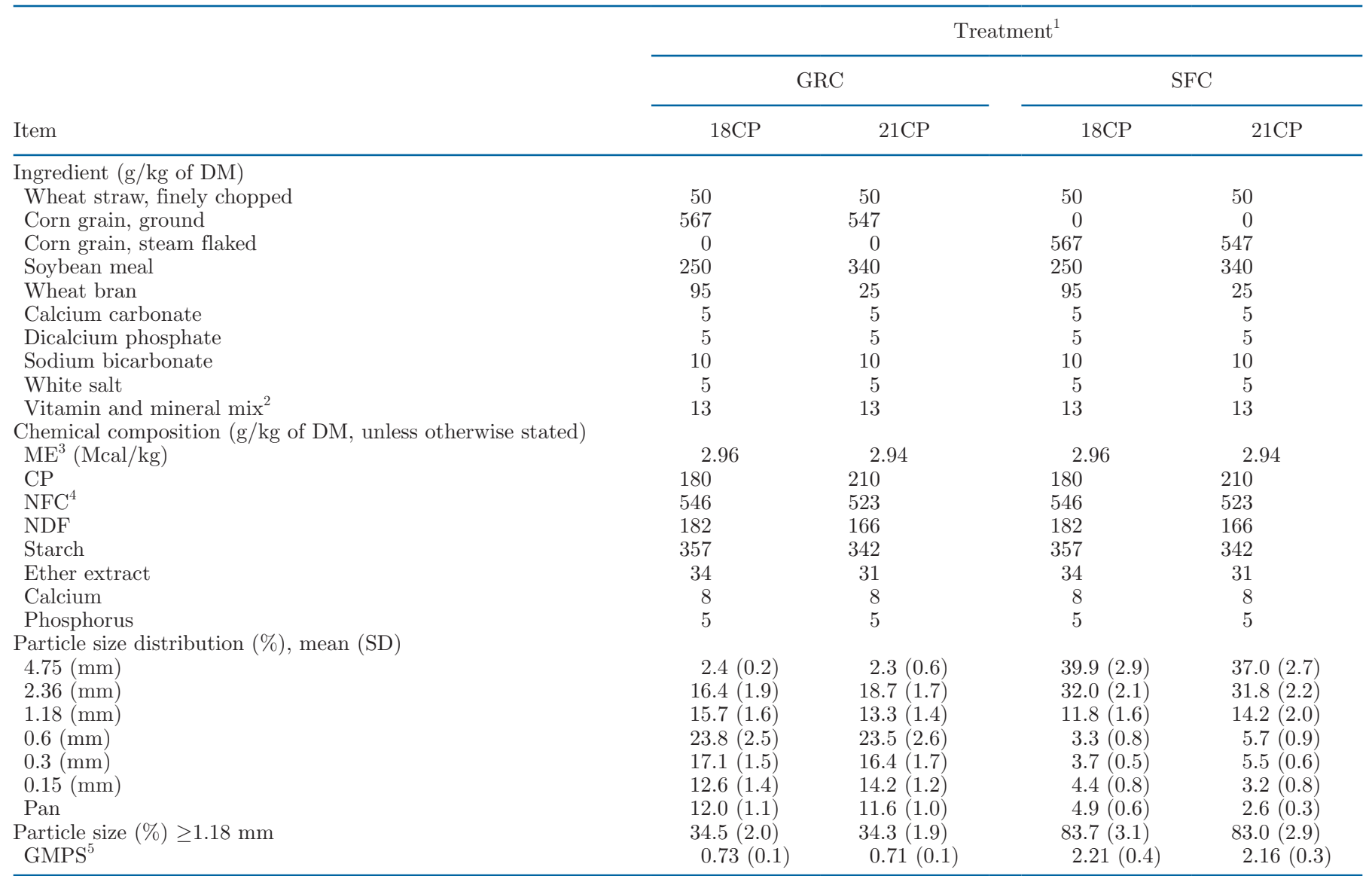

${ }^{1}$ Treatments were as follows: starter diet contained ground corn grain with 18\% CP (GRC-18CP), starter diet contained ground corn grain with $21 \%$ CP (GRC-21CP), starter diet contained steam-flaked corn grain with 18\% CP (SFC-18CP), and starter diet contained steam-flaked corn grain with $21 \% \mathrm{CP}$ (SFC-21CP).

${ }^{2}$ Contained per kilogram of supplement: 800,000 IU of vitamin A, 200,000 IU of vitamin D, 1,200 IU of vitamin E, $90 \mathrm{~g}$ of Ca, $2 \mathrm{~g}$ of Zn, $60 \mathrm{~g}$ of $\mathrm{P}, 12 \mathrm{~g}$ of $\mathrm{Mg}, 10 \mathrm{~g}$ of $\mathrm{Na}, 2 \mathrm{~g}$ of Fe, $50 \mathrm{mg}$ of $\mathrm{Co}, 200 \mathrm{mg}$ of $\mathrm{Cu}, 40 \mathrm{mg}$ of $\mathrm{I}, 1 \mathrm{~g}$ of $\mathrm{Mn}$, and $2 \mathrm{mg}$ of Se.

${ }^{3}$ Calculated from NRC (2001).

${ }^{4} \mathrm{NFC}$ was calculated as $[100-(\mathrm{NDF}+\mathrm{CP}+$ ether extract + ash $)](\mathrm{NRC}, 2001)$.

${ }^{5} \mathrm{GMPS}=$ geometric mean particle size, calculated as described by the American Society of Agricultural Engineers (1995).

(Van Keulen and Young, 1977). Apparent nutrient digestibility was calculated based on the concentrations of nutrients and acid insoluble ash in the feed (corrected for refusals) and fecal samples. The fecal content of NFC and its digestibility were calculated based on the equation for feed NFC (NRC, 2001).

Growth measurements, including heart girth (circumference of the chest), body length (distance between the points of shoulder and rump), body girth (circumference of the belly behind the shoulders before feeding), withers height (distance from the base of the front feet to withers), hip height (length from the base of the rear feet to the hook bones), and hip width (distance between the points of hook bones) were recorded at $\mathrm{d} 3, \mathrm{~d}$ 63 (weaning), and d 83 of age according to the method described by Khan et al. (2007) for dairy calves.
Ruminal fluid $(30 \mathrm{~mL})$ was collected 3 to $4 \mathrm{~h}$ after morning feeding (at 1100 to $1200 \mathrm{~h}$ ) on d 39 (preweaning) and d 78 (postweaning) using a stomach tube fitted to a vacuum pump. The first $10 \mathrm{~mL}$ was discarded to eliminate potential saliva contamination on ruminal fermentation patterns. Ruminal fluid samples were squeezed through 4 layers of cheesecloth. An aliquot $(10 \mathrm{~mL})$ was preserved with $2 \mathrm{~mL}$ of $25 \%$ metaphosphoric acid and frozen at $-20^{\circ} \mathrm{C}$. After thawing at room temperature, samples were analyzed for VFA concentrations using GRC (model CP-9002, Chrompack, Delft, the Netherlands) as described previously (Kazemi-Bonchenari et al., 2016). For measuring ruminal $\mathrm{NH}_{3}-\mathrm{N}$ concentration, ruminal fluid subsamples were thawed at room temperature and clarified by centrifugation $\left(15,000 \times g\right.$ for $20 \mathrm{~min}$ at $\left.4^{\circ} \mathrm{C}\right)$. The clarified 
supernatant was then decanted and analyzed for $\mathrm{NH}_{3}-\mathrm{N}$ using a modified phenol-hypochlorite method adapted from Broderick and Kang (1980).

The ruminal MPS was estimated based on the purine derivative (PD) excretion obtained via the spot sampling technique explained by Valadares et al. (1999). As milk contains PD (Gonzalez-Ronquillo et al., 2003) and could cause error in estimating PD excretion results obtained in preweaning calves, the spot urine sampling technique was used for MPS estimation only in the postweaning period when calves received no milk. Urine volumes were estimated as $\mathrm{BW} \times 26.8 /$ creatinine concentration $(\mathrm{mg} / \mathrm{L})$ in postweaned dairy calves as reported by Dennis et al. (2018). Spot urine samples were collected on $3 \mathrm{~d}$ during the postweaning period from each calf during the morning (between 0900 and $1100 \mathrm{~h}$ ) and during the afternoon (between 1500 and $1700 \mathrm{~h}$ ). Samples (approximately $10 \mathrm{~mL}$ ) were collected when calves urinated spontaneously. An aliquot of 5 $\mathrm{mL}$ of each sample was diluted immediately with 45 $\mathrm{mL}$ of $0.036 \mathrm{~N}$ sulfuric acid, then stored at $-20^{\circ} \mathrm{C}$ for analysis. Later, urine samples were thawed at room temperature and analyzed to determine the concentrations of creatinine (kit no. 555-A, Sigma Chemical Co., St. Louis, MO), urea N (UN; using the assay described by Broderick and Kang, 1980), and uric acid (kit no. 685-50, Sigma Chemical Co). Allantoin was measured using the HPLC method described by Chen and Gomes (1992). Total excretion of allantoin and uric acid were calculated from estimated daily urine output and determined metabolite concentrations. The ruminal microbial $\mathrm{N}$ synthesis was calculated from daily urinary $\mathrm{PD}$ output using the following equation described by Chen and Gomes (1992): microbial N $(\mathrm{g}$ of $\mathrm{N} / \mathrm{d})=\mathrm{X}$ $(\mathrm{mmol} / \mathrm{d}) \times 70 /(0.116 \times 0.83 \times 1,000)$, where $\mathrm{X}$ is microbial purine absorbed $(\mathrm{mmol} / \mathrm{d}), 70$ is the $\mathrm{N}$ content of purines coefficient ( $\mathrm{mg}$ of $\mathrm{N} / \mathrm{mmol}$ ), 0.116 is the ratio of purine $\mathrm{N}$ to total $\mathrm{N}$ in mixed ruminal microbes, which is 11.6:100, and 0.83 is the average digestibility of microbial purines (Chen and Gomes, 1992).

At the start of the experiment on d 3, the average blood serum total protein concentration of calves (kit no. 9304, Pars Azmoon Co., Tehran, Iran) was measured. The values were $6.28,6.10,6.12$, and $6.30 \mathrm{mg} /$ dL for GRC-18CP, GRC-21CP, SFC-18CP, and SFC$21 \mathrm{CP}$, respectively. Only calves with a blood total protein concentration $>5.7 \mathrm{mg} / \mathrm{dL}$ were included in the study. The blood samples for the experimental period were collected on d 40 (preweaning) and d 80 (postweaning) $4 \mathrm{~h}$ after the morning feeding (at $1200 \mathrm{~h}$ ) from the jugular vein into $10-\mathrm{mL}$ tubes, placed on ice, and centrifuged at $3,000 \times g$ for $20 \mathrm{~min}$ at $4^{\circ} \mathrm{C}$. Serum subsamples stored at $-20^{\circ} \mathrm{C}$ were subsequently analyzed to determine concentrations of glucose (kit no. 93008), albumin (kit no. 9307), total protein (kit no. 9304), and BUN (kit no. 93013) using commercial kits in accordance with the manufacturer's instructions (Pars Azmoon Co.). $\beta$-Hydroxybutyrate was measured with a commercial kit (Abbott Diabetes Care Ltd., Oxin, UK). The liver function indicator enzymes, aspartate aminotransferase (AST) and alanine aminotransferase (ALT), were measured using ELISA (Auto Analyzer Hitachi 717 Instruments Inc., Tokyo, Japan) and commercial laboratory kits (kit no. 92005 and 92004 for AST and ALT, respectively). Insulin concentration in serum was determined using ELISA (Auto Analyzer Hitachi 717).

\section{Statistical Analysis}

Data were analyzed as a completely random design with a $2 \times 2$ factorial arrangement of treatments with the factors of corn grain processing method (GRC vs. SFC) and starter CP content (18\% vs. $21 \%$, DM basis). The MIXED procedure of SAS (SAS 9.1, SAS Institute Inc., Cary, NC) was used. Repeated measures were used when variables were measured over time. The model included fixed effects of time (sampling date), corn grain processing method, starter $\mathrm{CP}$ content, and their interactions, with calf as a random effect. Sex was not significant and was dropped from the model. Initial BW and structural growth were considered as covariates for the weaning (d 63) and final (d 83) BW and skeletal growth analysis, respectively. Before analyses, all data were screened for normality using the UNIVARIATE procedure of SAS. Two variance-covariance structures (auto-regressive type 1 and compound symmetry) were tested and the covariance structure that minimized the Schwarz's Bayesian information criterion was chosen. The fecal score was square-root transformed for better homogeneity of the distribution of residuals. Ruminal fermentation characteristics, structural growth, digestibility, UN, PD excretion, MPS, and blood metabolite variables were analyzed using a similar model, but without the effect of time. The main effects of corn processing and starter CP level, as well as corn processing $x$ diet $\mathrm{CP}$ interaction were tested using ANOVA. The threshold of significance was set at $P \leq 0.05$; trends were declared at $0.05<P \leq 0.10$.

\section{RESULTS}

\section{Particle Size Distribution of Starter Diets}

Compared with the GRC starter diets, the SFC starter diets had more particles retained on the top 
screen (i.e., 4.75-mm screen), resulting in the greatest GMPS of $0.73 \pm 0.1 \mathrm{~mm}$ for GRC-18CP, $0.71 \pm 0.1 \mathrm{~mm}$ for GRC-21CP, $2.21 \pm 0.4 \mathrm{~mm}$ for SFC-18CP, and 2.16 $\pm 0.3 \mathrm{~mm}$ for SFC-21CP (Table 1). Particles retained on the $4.75-\mathrm{mm}$ screen were predominantly coarse fragments of corn grain with a small amount of wheat straw particles, as wheat straw was finely chopped and its particles passed to the screens below.

\section{Intake and Growth Performance}

Starter intake, total DMI, ADG, and FE data are presented in Table 2. The starter feed intake did not differ among treatments. The ADG was greater $(P=$ $0.02)$ for the SFC diets than with the GRC diets during the preweaning $(P=0.05)$ and entire periods (Figure 1 ). The FE was greater for calves fed the SFC diets compared with the GRC diets during the preweaning (tendency, $P=0.08)$, preweaning $(P=0.01)$, and entire $(P=0.03)$ periods (Figure 2$)$. Starter protein content did not influence starter feed intake, ADG, or FE. No interactions of main effects were observed on starter feed intake, total DMI, ADG, and FE.
The skeletal growth and BW data are presented in Table 3. The final BW was greater for calves fed the SFC diets than for calves fed the GRC diets $(P=$ $0.02)$. No differences were observed among treatments for heart girth, body length, body girth, and hip width. An interaction was observed between corn processing and $\mathrm{CP}$ contents of the diets for withers height and hip height with the greatest $(P<0.05)$ values for calves fed the SFC-21CP treatment.

\section{Ruminal Fermentation}

The ruminal fermentation data are presented in Table 4. Ruminal $\mathrm{NH}_{3}-\mathrm{N}$ concentrations were greater $(P=0.01)$ for calves fed the SFC diets compared with those fed the GRC diets during the postweaning period. Ruminal $\mathrm{NH}_{3}-\mathrm{N}$ concentration tended to be higher $(P$ $=0.07$ ) for calves fed the $21 \%$ versus $18 \% \mathrm{CP}$ diets during the postweaning period. The ruminal concentration of VFA was greater for the SFC diets compared with the GRC diets during both the preweaning $(P=0.03)$ and postweaning periods $(P=0.04)$. Acetate concentration was increased in GRC-fed calves preweaning $(P$

Table 2. Least squares means for starter intake, ADG, and feed efficiency in dairy calves fed starters differing in corn grain processing methods (ground corn vs. steam-flaked corn) with different starter protein content (18 vs. $21 \%$, DM basis; $\mathrm{n}=12$ calves per treatment)

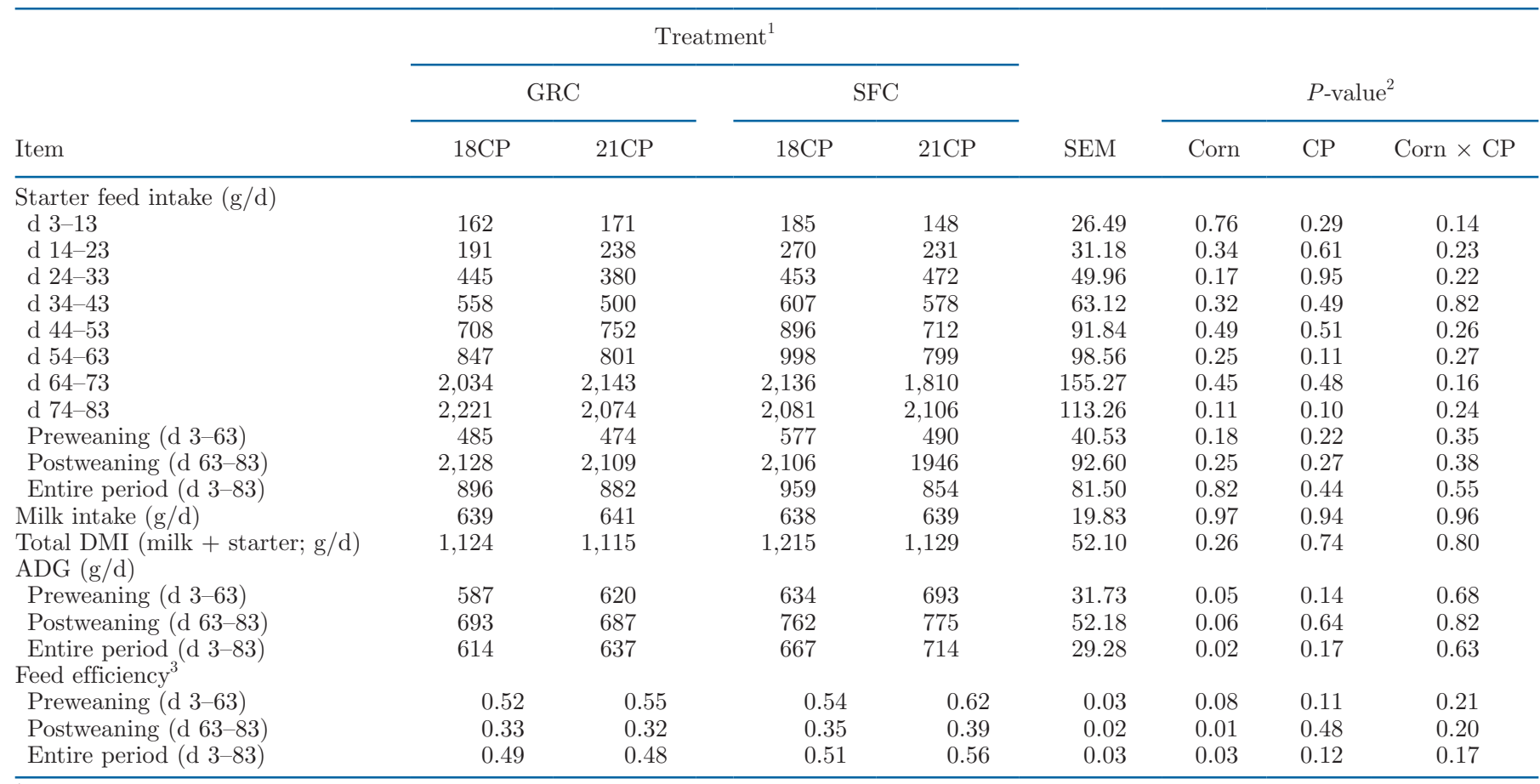

${ }^{1}$ Treatments were as follows: starter diet contained ground corn grain with $18 \%$ CP (GRC-18CP), starter diet contained ground corn grain with 21\% CP (GRC-21CP), starter diet contained steam-flaked corn grain with 18\% CP (SFC-18CP), and starter diet contained steam-flaked corn grain with $21 \% \mathrm{CP}$ (SFC-21CP).

${ }^{2}$ Statistical comparisons: corn $=$ corn grain processing method (ground corn grain vs. steam-flaked corn grain); CP $=18$ vs. $21 \%$ dietary starter protein content based on $\mathrm{DM}$; corn $\times \mathrm{CP}=$ interaction of grain processing method and dietary starter protein content.

${ }^{3} \mathrm{~kg}$ of BW gain $/ \mathrm{kg}$ of total DMI. 
$=0.01)$, but in contrast, ruminal propionate $(P=0.05)$ and butyrate $(P=0.02)$ concentrations were increased in SFC-fed calves before weaning. Acetate concentration tended to be greater in calves fed the starter with greater $\mathrm{CP}$ content $(P=0.06)$. The acetate:propionate ratio was greater $(P=0.01)$ for calves fed the GRC diets compared with those fed the SFC diets during the preweaning period. The ruminal concentration of branched-chain volatile fatty acids (BCVFA) tended to be greater $(P=0.06)$ for calves fed the $21 \%$ versus $18 \%$ CP diets. No interaction between main effects occurred for ruminal fermentation variables.

\section{Fecal Score and Nutrient Digestibility}

Although fecal scores did not differ significantly among experimental treatments when considering the entire experiment, fecal score was greater during the first $30 \mathrm{~d}$ of the experiment for calves fed the GRC diets compared with the SFC diets (Figure 3). The digestibilities of $\mathrm{OM}(P=0.03)$ and NFC $(P=0.01)$ were greater for calves fed the SFC diets compared with the GRC diets (Table 5). Digestibility of NDF was greater for $21 \mathrm{CP}$ diets compared with $18 \mathrm{CP}$ diets $(P=0.04)$.

\section{Microbial Protein Synthesis and Urinary N Excretion}

Results for urinary PD, MPS, and UN excretion during the postweaning period are presented in Table 5. Allantoin excretion in urine was greater $(P=0.05)$ for calves fed the SFC diets compared with the GRC diets. No differences were observed among treatments for uric acid in urine. The urinary PD excretion $(P$ $=0.04)$ and MPS were greater $(P=0.04)$ for calves fed the SFC diets compared with the GRC diets. The UN concentration $(P=0.02)$ and $\mathrm{UN}$ excretion as a proportion of total $\mathrm{N}$ intake $(P=0.01)$ were lower for calves fed the SFC diets compared with the GRC diets. The amount of $\mathrm{N}$ intake tended to be greater in $21 \%$ CP diets compared with $18 \%$ CP diets during the MPS measurements $(P=0.09)$. No interaction between main effects was observed for urinary PD, N intake, MPS, and UN excretion.

\section{Blood Metabolites and Hormone}

The blood metabolites and hormone data are presented in Table 6. No interaction between main effects was observed for blood metabolites and hormones.

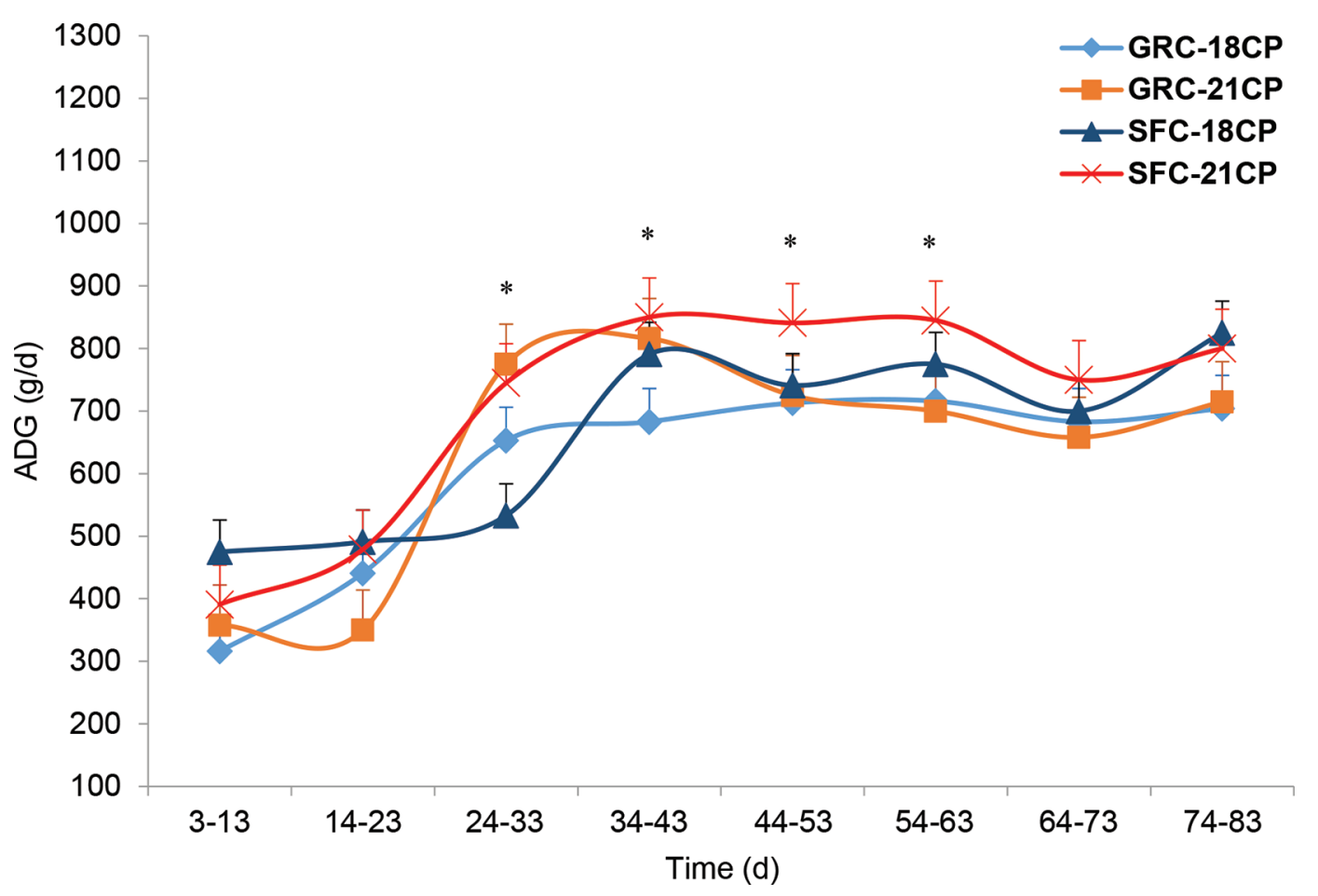

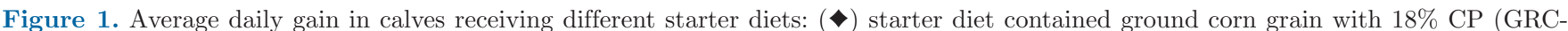

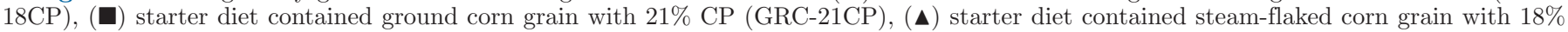
$\mathrm{CP}(\mathrm{SFC}-18 \mathrm{CP})$, and $(\times)$ starter diet contained steam-flaked corn grain with $21 \% \mathrm{CP}$ (SFC-21CP). Asterisks indicate a significant difference $\left({ }^{*} P<0.05\right)$ between groups at a given time point. Error bars represent SEM. 
Postweaning blood glucose concentration $(P=0.03)$ and preweaning BHB concentration $(P=0.04)$ were greater but preweaning BUN concentration was lower $(P=0.05)$ for calves fed the SFC diets compared with the GRC diets. The postweaning BUN concentration tended to be greater $(P=0.09)$ for calves fed the $21 \%$ $\mathrm{CP}$ diets compared with those fed the $18 \% \mathrm{CP}$ diets. Blood insulin concentration was greater $(P<0.05)$ for calves fed the SFC diets compared with the GRC diets during both the pre- and postweaning periods. No differences were observed among treatments for liver enzyme concentrations.

\section{DISCUSSION}

\section{Particle Size Distribution of Starter Diets}

Predictably, corn grain processing influenced the PS of starter feeds. Corn grain was incorporated in the starter feed as the sole grain source in the form of GRC or SFC. The SFC diets contained large amounts of coarse particles $($ GMPS value $=2.18 \mathrm{~mm}$ ), but GRC had a considerable amount of fine particles (GMPS value $=0.72 \mathrm{~mm}$ ); hence, PS and grain processing were expected to affect intake and digestibility.
Mojahedi et al. (2018) fed dairy calves with corn grain processed by different methods, and reported GMPS values equal to 1.58 and $2.13 \mathrm{~mm}$ for cracked and SFC grains, respectively. Gimeno et al. (2015) reported the GMPS for corn ground using a 3.5-mm sieve was 0.74 $\mathrm{mm}$, which is similar to our GMPS results for GRC diets. When $15 \%$ corn silage (DM basis) was included in a mashed or textured starter diet, geometric mean particle length was 1.3 and $3.0 \mathrm{~mm}$, compared with GMPS for starter without forage included of $0.50 \mathrm{~mm}$ (Mirzaei et al., 2016). As expected, the lowest GMPS in grain processing is for grinding, followed by rolling and steam flaking. These results show that in addition to the grain processing methods that altered GMPS of our starter diets, other factors such as forage source, amount, and PS could affect the PS distribution of starter diets, which subsequently may influence animal performance.

\section{Effect of Corn Processing}

In the current study, there was no difference in the starter intake between calves fed GRC and SFC diets. Grinding grains into small PS for calves reduced intake (Bateman et al., 2009), which is partly related to ru-

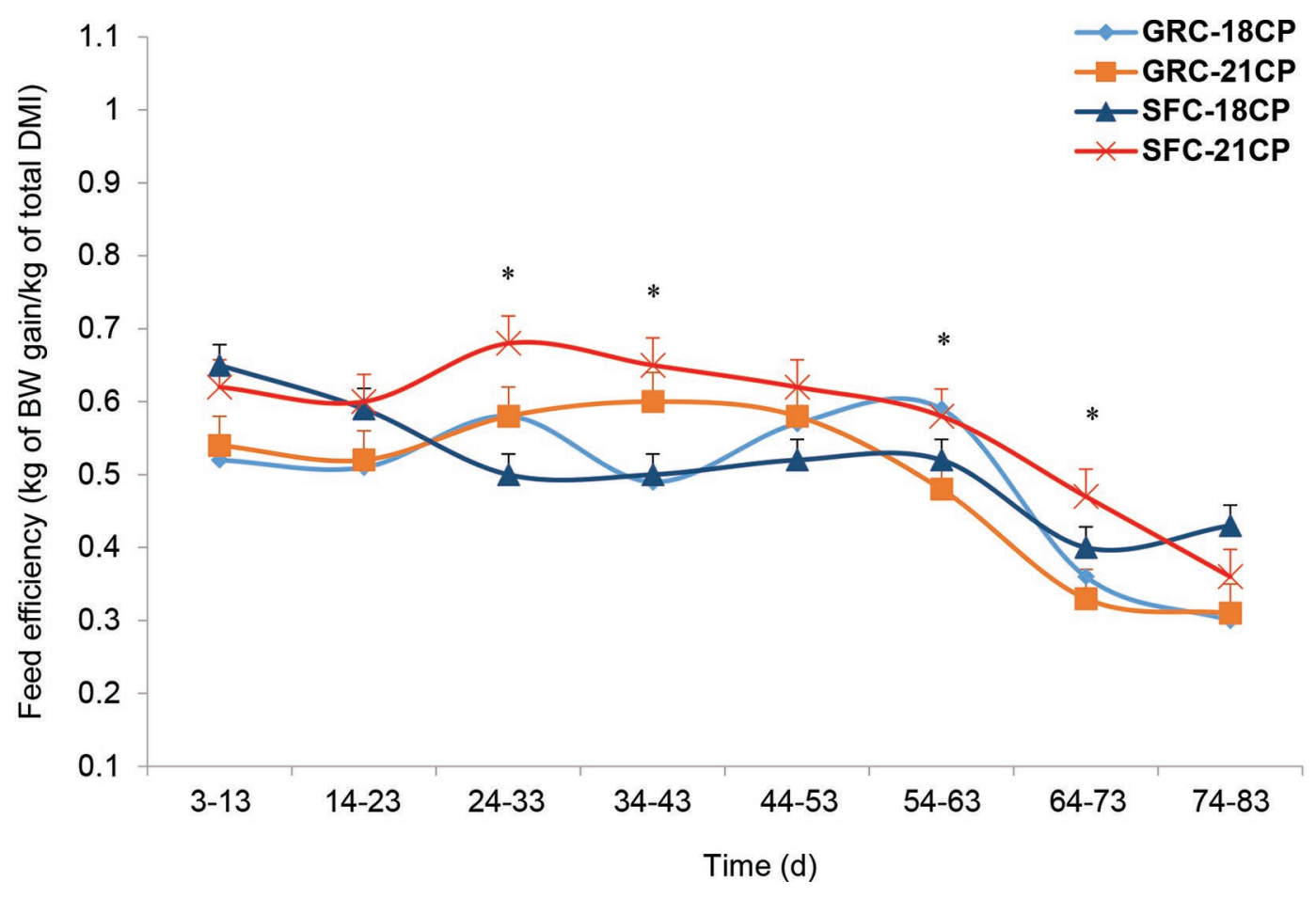

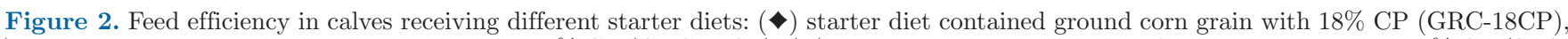

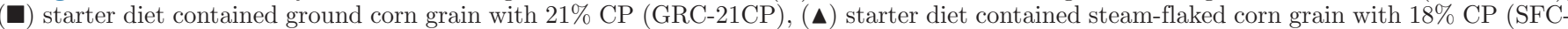
$18 \mathrm{CP}$ ), and $(\times)$ starter diet contained steam-flaked corn grain with $21 \% \mathrm{CP}(\mathrm{SFC}-21 \mathrm{CP})$. Asterisks indicate a significant difference $(* P<0.05)$ between groups at a given time point. Error bars represent SEM. 
minal pH decline (Khan et al., 2008) due to increased surface area for ruminal fermentation. In some situations, increased lactate, which is a very potent acid (10 times stronger than VFA), further contributes to impair intake of calves (Khan et al., 2008; Bateman et al., 2009; Kazemi-Bonchenari et al., 2017). We speculate that the inclusion of chopped wheat straw (5\%, DM basis) blended with the starter feed, might have masked possible effects of grain processing on feed intake. The included forage amount was based on the suggested amount of approximately $5 \%$ forage in diets due to the limited capacity of the rumen, as well as limited ability to digest high-fiber feeds (Aragona et al., 2020).
In the current trial, the ADG and FE were improved in calves fed the SFC diets compared with those fed the GRC diets. Calves fed the SFC diets had greater final $\mathrm{BW}(+5.6 \mathrm{~kg})$ as well as greater overall $\mathrm{FE}(+0.05)$ compared with those fed the GRC diets. Similar results were observed by Mojahedi et al. (2018), in which ADG was greater for calves fed on SFC-based diets compared with those fed cracked corn-based diets blended with forage (10\% of DM). The greater FE observed when feeding the SFC diets may be attributed to the higher digestibility of OM and NFC. Because the limited fecal sampling in the current study (2 fecal grab samples per day for 5 consecutive days) demands that digestibility

Table 3. Least squares means for BW and structural growth indices in dairy calves fed starters differing in corn grain processing methods (ground corn vs. steam-flaked corn) with different starter protein content (18 vs. $21 \%$, DM basis; $\mathrm{n}=12$ calves per treatment)

\begin{tabular}{|c|c|c|c|c|c|c|c|c|}
\hline \multirow[b]{3}{*}{ Item } & \multicolumn{4}{|c|}{ Treatment $^{1}$} & \multirow[b]{3}{*}{ SEM } & \multirow{2}{*}{\multicolumn{3}{|c|}{$P$-value ${ }^{2}$}} \\
\hline & \multicolumn{2}{|c|}{ GRC } & \multicolumn{2}{|c|}{$\mathrm{SFC}$} & & & & \\
\hline & $18 \mathrm{CP}$ & $21 \mathrm{CP}$ & $18 \mathrm{CP}$ & $21 \mathrm{CP}$ & & Corn & $\mathrm{CP}$ & Corn $\times \mathrm{CP}$ \\
\hline \multicolumn{9}{|l|}{ BW } \\
\hline d 3 (initial) & 39.3 & 39.6 & 40.2 & 38.9 & 0.84 & 0.73 & 0.32 & 0.29 \\
\hline d 13 & 42.3 & 42.9 & 43.7 & 42.2 & 1.27 & 0.29 & 0.25 & 0.11 \\
\hline d 23 & 46.7 & 46.4 & 48.1 & 47.0 & 1.33 & 0.10 & 0.16 & 0.24 \\
\hline d 33 & 53.9 & 54.1 & 56.4 & 54.2 & 1.38 & 0.06 & 0.60 & 0.57 \\
\hline d 43 & 59.8 & 62.8 & 64.0 & 62.9 & 1.43 & 0.08 & 0.66 & 0.30 \\
\hline d 53 & 67.2 & 70.5 & 71.3 & 72.0 & 1.50 & 0.09 & 0.37 & 0.47 \\
\hline d 63 (weaning) & 74.4 & 76.5 & 79.0 & 79.9 & 1.55 & 0.07 & 0.49 & 0.76 \\
\hline d 73 & 81.2 & 84.7 & 88.3 & 88.9 & 1.71 & 0.05 & 0.38 & 0.53 \\
\hline d 83 (final) & 89.2 & 91.3 & 95.2 & 96.4 & 1.58 & 0.02 & 0.47 & 0.82 \\
\hline \multicolumn{9}{|c|}{ Structural growth indices } \\
\hline \multicolumn{9}{|c|}{ Heart girth } \\
\hline Initial (d 3) & 78.2 & 77.3 & 79.0 & 79.5 & 0.70 & 0.23 & 0.96 & 0.34 \\
\hline Weaning (d 63) & 97.2 & 95.7 & 96.2 & 99.7 & 1.09 & 0.33 & 0.52 & 0.10 \\
\hline Final (d 83) & 101.8 & 101.0 & 100.6 & 105.1 & 1.16 & 0.36 & 0.27 & 0.11 \\
\hline \multicolumn{9}{|l|}{ Body length } \\
\hline Initial (d 3) & 44.0 & 42.8 & 43.2 & 44.2 & 0.54 & 0.66 & 0.91 & 0.16 \\
\hline Weaning (d 63) & 49.8 & 50.2 & 50.5 & 51.0 & 0.66 & 0.44 & 0.60 & 0.93 \\
\hline Final (d 83) & 53.0 & 52.1 & 52.7 & 53.6 & 0.71 & 0.45 & 0.93 & 0.28 \\
\hline \multicolumn{9}{|l|}{ Body girth } \\
\hline Initial (d 3) & 79.3 & 79.6 & 80.0 & 80.2 & 0.75 & 0.41 & 0.72 & 0.90 \\
\hline Weaning (d 63) & 104 & 102 & 102 & 108 & 1.82 & 0.51 & 0.51 & 0.13 \\
\hline Final (d 83) & 112 & 111 & 111 & 114 & 1.56 & 0.64 & 0.80 & 0.38 \\
\hline \multicolumn{9}{|l|}{ Wither height } \\
\hline Initial (d 3) & 75.5 & 75.4 & 76.6 & 75.9 & 0.72 & 0.22 & 0.96 & 0.94 \\
\hline Weaning (d 63) & $87.3^{\mathrm{ab}}$ & $85.7^{\mathrm{b}}$ & $85.6^{\mathrm{b}}$ & $89.9^{\mathrm{a}}$ & 0.89 & 0.32 & 0.29 & 0.02 \\
\hline Final (d 83) & $90.0^{\mathrm{b}}$ & $88.1^{\mathrm{b}}$ & $88.3^{\mathrm{b}}$ & $92.5^{\mathrm{a}}$ & 0.97 & 0.29 & 0.35 & 0.03 \\
\hline \multicolumn{9}{|l|}{ Hip height } \\
\hline Initial (d 3) & 78.6 & 79.2 & 80.6 & 79.5 & 0.76 & 0.22 & 0.63 & 0.89 \\
\hline Weaning (d 63) & $90.3^{\mathrm{b}}$ & $88.1^{\mathrm{b}}$ & $88.8^{\mathrm{b}}$ & $92.9^{\mathrm{a}}$ & 0.86 & 0.16 & 0.34 & 0.01 \\
\hline Final (d 83) & $92.6^{\mathrm{b}}$ & $90.7^{\mathrm{b}}$ & $90.9^{\mathrm{b}}$ & $94.6^{\mathrm{a}}$ & 1.02 & 0.12 & 0.21 & 0.02 \\
\hline \multicolumn{9}{|l|}{ Hip width } \\
\hline Initial (d 3) & 16.5 & 16.8 & 16.3 & 16.7 & 0.20 & 0.15 & 0.16 & 0.62 \\
\hline Weaning (d 63) & 19.4 & 19.3 & 19.5 & 20.2 & 0.28 & 0.12 & 0.30 & 0.22 \\
\hline Final (d 83) & 20.8 & 20.9 & 21.0 & 22.2 & 0.31 & 0.12 & 0.25 & 0.17 \\
\hline
\end{tabular}

${ }^{\mathrm{a}, \mathrm{b}}$ Means within a row with different superscript letters are different $(P<0.05)$.

${ }^{1}$ Treatments were as follows: starter diet contained ground corn grain with $18 \%$ CP (GRC-18CP), starter diet contained ground corn grain with $21 \%$ CP (GRC-21CP), starter diet contained steam-flaked corn grain with 18\% CP (SFC-18CP), and starter diet contained steam-flaked corn grain with $21 \% \mathrm{CP}$ (SFC-21CP).

${ }^{2}$ Statistical comparisons: corn $=$ corn grain processing method (ground corn grain vs. steam-flaked corn grain); CP $=18$ vs. $21 \%$ dietary starter protein content based on DM; corn $\times \mathrm{CP}=$ interaction of grain processing method and dietary starter protein content. 
Table 4. Least squares means for ruminal fermentation patterns in dairy calves fed starters differing in corn grain processing methods (ground corn vs. steam-flaked corn) with different starter protein content (18 vs. $21 \%$, DM basis) ( $\mathrm{n}=12$ calves per treatment)

\begin{tabular}{|c|c|c|c|c|c|c|c|c|}
\hline Item & \multicolumn{4}{|c|}{ Treatment $^{1}$} & SEM & \multicolumn{3}{|c|}{$P$-value ${ }^{2}$} \\
\hline \multicolumn{9}{|l|}{ Ruminal $\mathrm{NH}_{3}-\mathrm{N}(\mathrm{mg} / \mathrm{dL})$} \\
\hline d 39 & 10.8 & 12.1 & 10.1 & 10.5 & 0.45 & 0.08 & 0.23 & 0.45 \\
\hline d 78 & 13.5 & 14.9 & 11.4 & 12.5 & 0.65 & 0.01 & 0.07 & 0.75 \\
\hline d 78 & 108 & 111 & 115 & 122 & 3.21 & 0.04 & 0.19 & 0.61 \\
\hline \multicolumn{9}{|l|}{ Individual VFA (mM/100 mmol) } \\
\hline \multicolumn{9}{|l|}{ Acetate $(\mathrm{A})$} \\
\hline d 39 & 52.0 & 49.9 & 48.0 & 45.3 & 1.03 & 0.01 & 0.06 & 0.93 \\
\hline d 78 & 51.9 & 51.8 & 51.5 & 48.9 & 0.75 & 0.16 & 0.20 & 0.23 \\
\hline \multicolumn{9}{|l|}{ Propionate $(\mathrm{P})$} \\
\hline d 39 & 30.4 & 32.1 & 32.8 & 34.4 & 0.79 & 0.05 & 0.17 & 0.98 \\
\hline d 39 & 11.2 & 11.7 & 14.6 & 14.4 & 0.98 & 0.02 & 0.91 & 0.77 \\
\hline d 78 & 9.8 & 10.1 & 9.0 & 9.9 & 1.19 & 0.75 & 0.72 & 0.85 \\
\hline \multicolumn{9}{|l|}{$\mathrm{BCVFA}^{3}$} \\
\hline d 39 & 5.2 & 6.1 & 4.4 & 5.7 & 0.45 & 0.36 & 0.06 & 0.74 \\
\hline d 78 & 5.1 & 4.3 & 4.1 & 4.6 & 0.30 & 0.46 & 0.72 & 0.18 \\
\hline Milk DMI, d 39 (g) & 838 & 836 & 840 & 838 & 4.67 & 0.42 & 0.42 & 1.0 \\
\hline Starter intake, d 39 (g) & 567 & 587 & 610 & 593 & 47.12 & 0.21 & 0.93 & 0.35 \\
\hline Total DMI (milk DM + starter), d 39 (g) & 1,405 & 1,423 & 1,450 & 1,431 & 38.19 & 0.15 & 0.97 & 0.32 \\
\hline Starter intake, d 78 (g) & 2,204 & 2,114 & 2,166 & 2,159 & 90.23 & 0.91 & 0.18 & 0.23 \\
\hline
\end{tabular}

${ }^{1}$ Treatments were as follows: starter diet contained ground corn grain with 18\% CP (GRC-18CP), starter diet contained ground corn grain with 21\% CP (GRC-21CP), starter diet contained steam-flaked corn grain with 18\% CP (SFC-18CP), and starter diet contained steam-flaked corn grain with $21 \% \mathrm{CP}$ (SFC-21CP).

${ }^{2}$ Statistical comparisons: corn $=$ corn grain processing method (ground corn grain vs. steam-flaked corn grain); CP $=18$ vs. $21 \%$ dietary starter protein content based on $\mathrm{DM}$; corn $\times \mathrm{CP}=$ interaction of grain processing method and dietary starter protein content.

${ }^{3}$ Branched-chain volatile fatty acids (BCVFA) are the ruminal concentrations of valerate + isovalerate.

results should be interpreted with caution, the greater digestibility of SFC diets would result in more energy available for growth compared with the GRC diets. The higher digestibilities of OM and NFC may have been related to increased availability of carbohydrate of grains due to greater surface area and a greater capacity for microbial attachment in SFC (Owens et al., 1997; Theurer et al., 1999). Although starch digestibility was not measured in the current research, greater starch digestibility, as well as improved ADG typically seen with SFC as compared with dry-rolled corn, may have resulted from the extensive gelatinization and increased solubility of corn starch in the rumen (Zinn et al., 2002; Corona et al., 2005).

Previous research reported that the total-tract digestion of starch in dairy calves was higher $(98.7 \%)$ when they received low-starch pelleted starter compared with the lower starch digestibility (95\%) when calves were fed high-starch textured starter diets (Quigley et al., 2018). In contrast, Quigley et al. (2019) reported no difference in starch digestibility between dairy calves fed pelleted starter or a textured starter diet starch content in the diet was the same. We evaluated the incorporation of SFC in a meal-form starter diet rather than textured diets that have been discussed earlier; hence, the physical form of the complete starter may cause discrepancies in grain processing studies.

Improved fecal consistency in the early weeks of the experiment in dairy calves fed SFC diet may have been involved in better FE observed in calves fed SFC diets. Porter et al. (2007) suggested that ruminal function was improved when $75 \%$ of the particles in a starter exceed $1.19 \mathrm{~mm}$ in diameter. Our data showed that the average portion of PS greater than $1.19 \mathrm{~mm}$ was $34.4 \%$ and $83.3 \%$ for the GRC versus SFC diets, respectively. In agreement with Porter et al. (2007), SFC diets containing greater PS may have influenced gastrointestinal activity and improved fecal consistency.

In the current trial, diets containing SFC resulted in greater total ruminal VFA concentrations and greater 


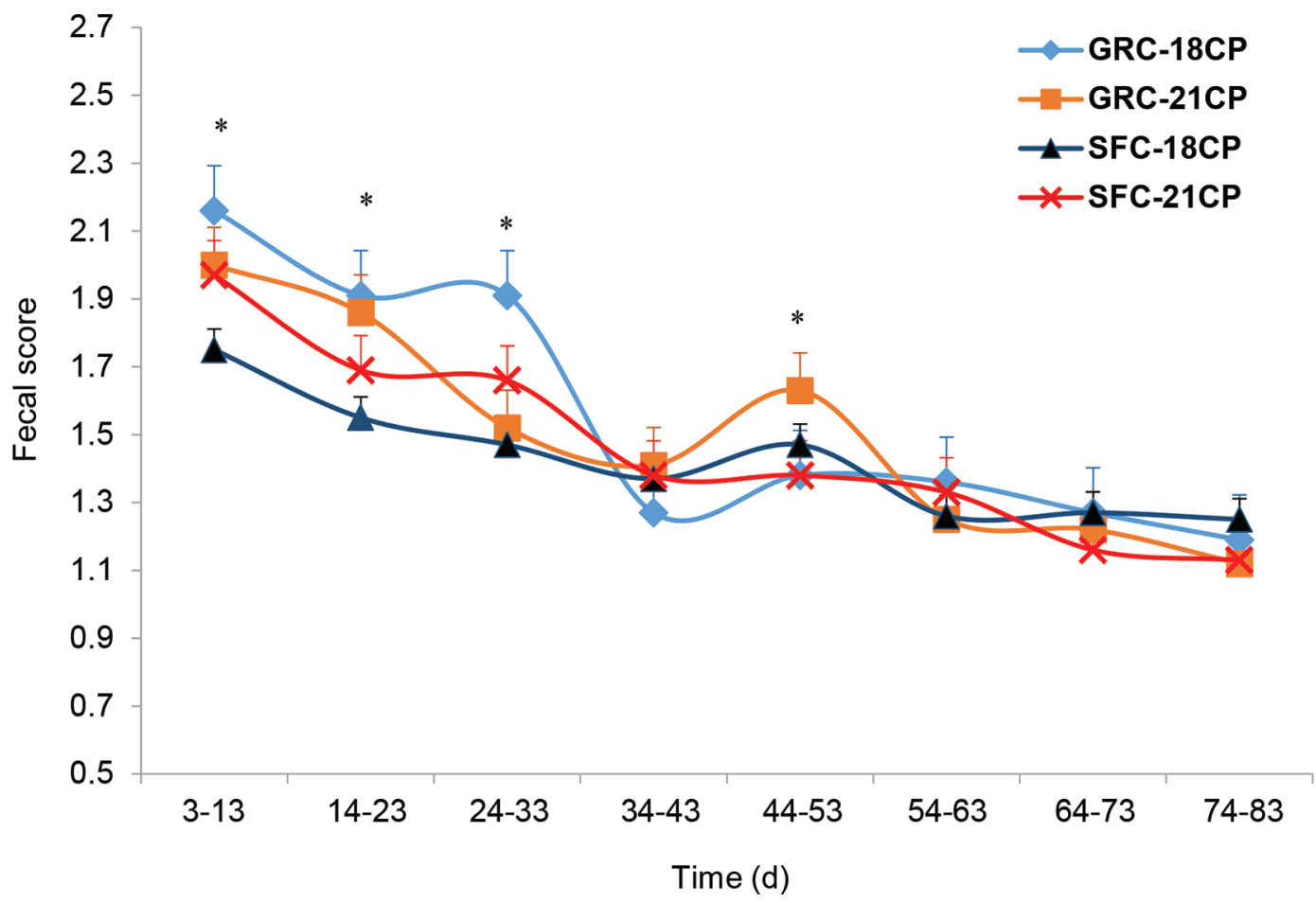

Figure 3. Fecal score (1 to 5 scale, with 1 being normal and 5 being watery) in calves receiving different starter diets: ( $)$ starter diet contained ground corn grain with $18 \% \mathrm{CP}(\mathrm{GRC}-18 \mathrm{CP}),(\boldsymbol{\square})$ starter diet contained ground corn grain with $21 \% \mathrm{CP}(\mathrm{GRC}-21 \mathrm{CP})$, ( $\mathbf{\Delta})$ starter diet contained steam-flaked corn grain with $18 \% \mathrm{CP}(\mathrm{SFC}-18 \mathrm{CP})$, and $(\times)$ starter diet contained steam-flaked corn grain with $21 \% \mathrm{CP}(\mathrm{SFC}-21 \mathrm{CP})$. Asterisks indicate a significant difference $\left({ }^{*} P<0.05\right)$ between groups at a given time point. Error bars represent SEM.

Table 5. Least squares means for nutrient digestibility and microbial protein synthesis in dairy calves fed starters differing in corn grain processing methods (ground corn vs. steam-flaked corn) with different starter protein content (18 vs. $21 \%$, DM basis; $\mathrm{n}=12$ calves per treatment)

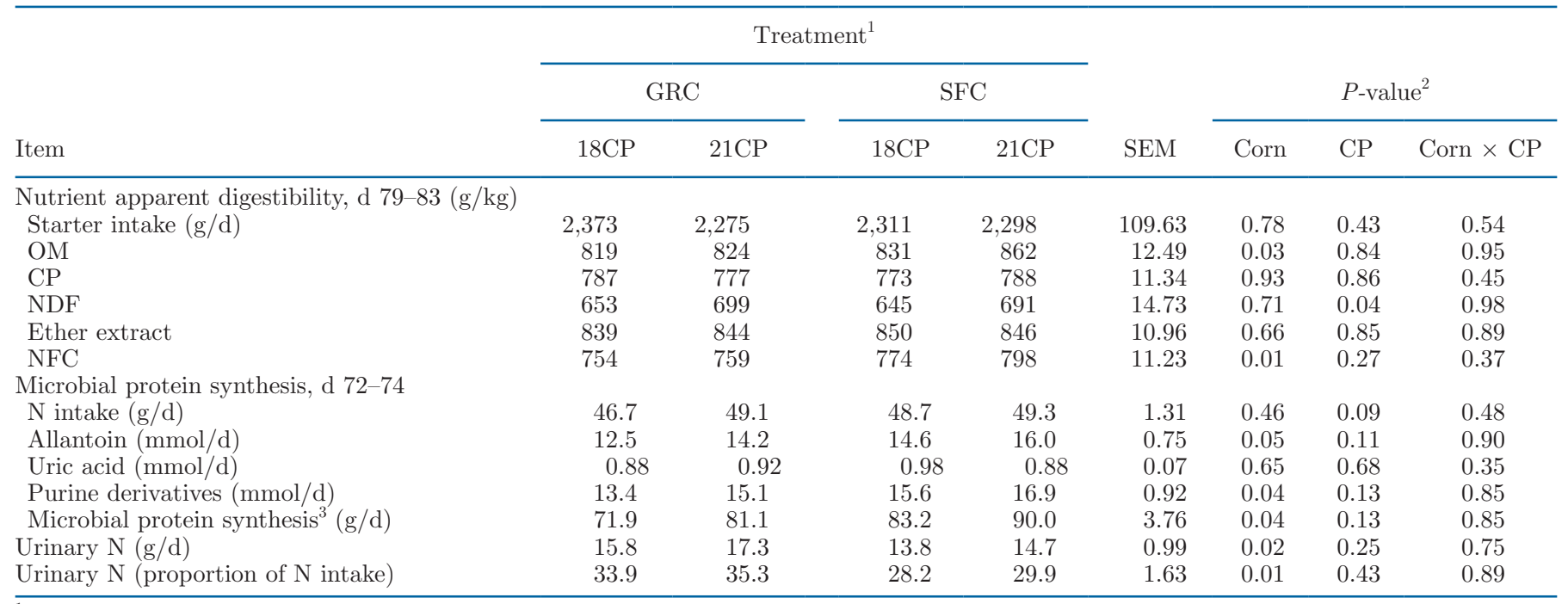

${ }^{1}$ Treatments were as follows: starter diet contained ground corn grain with 18\% CP (GRC-18CP), starter diet contained ground corn grain with $21 \%$ CP (GRC-21CP), starter diet contained steam-flaked corn grain with 18\% CP (SFC-18CP), and starter diet contained steam-flaked corn grain with $21 \%$ CP (SFC-21CP).

${ }^{2}$ Statistical comparisons: corn $=$ corn grain processing method (ground corn grain vs. steam-flaked corn grain); CP $=18$ vs. $21 \%$ dietary starter protein content based on $\mathrm{DM}$; corn $\times \mathrm{CP}=$ interaction of grain processing method and dietary starter protein content.

${ }^{3}$ Microbial protein synthesis calculated through urinary purine derivative excretion based on Chen and Gomes (1992). 
molar percentages of propionate and butyrate instead of acetate and BCVFA compared with the GRC diets during both preweaning and postweaning periods. These results might be attributable at least partially to the greater $\mathrm{OM}$ and NFC digestion in the rumen from the SFC diets compared with the GRC diets, which could supply more fermentable substrate for ruminal fermentation (Clark et al., 1992). As stated previously, the main energy source for ruminant tissues is VFA (Bergman, 1990) and hence the greater VFA concentration may indicate greater VFA supply and potential to improve ADG and FE. Previous work reported higher VFA concentration when steers were fed with processed grains (Murphy et al., 1994), which was due to greater ruminal starch digestibility (Theurer et al., 1999; Gimeno et al., 2015). The range of ruminal VFA concentrations in the current study was within the ranges reported for dairy calves in previous studies (Khan et al., 2008; Mirzaei et al., 2016; Omidi-Mirzaei et al., 2018). The difference in the molar percentage of individual VFA in the rumen (greater propionate and butyrate instead of acetate and BCVFA) in calves fed SFC diets partly explains improved ADG from the energetic efficiency point of view compared with the GRC diets. Propionate and butyrate are the 2 main VFA that supply greater energy on a molar basis than acetate (Annison, and Armstrong, 1970; Bergman, 1990), and hence have greater potential to improve animal performance. It is notable herein that all the diets were isoenergetic in the current trial.

We found lower ruminal $\mathrm{NH}_{3}-\mathrm{N}$ concentrations when calves were fed the SFC diets compared with the GRC diets. The lower ruminal $\mathrm{NH}_{3}-\mathrm{N}$ concentrations with the SFC diets may be an indicator of ruminal $\mathrm{N}$ utilization by ruminal microbes (Casper et al., 1999). This change is consistent with the BUN concentration (20.5 vs. 18.7 $\mathrm{mg} / \mathrm{dL}$ for the GRC and SFC diets, respectively) and urea $\mathrm{N}$ excreted as part of the urine (16.5 vs. $14.2 \mathrm{~g} / \mathrm{d}$ for the GRC and SFC diets, respectively). These results indicate that greater ruminal $\mathrm{NH}_{3}-\mathrm{N}$ concentration in the GRC diets increased both urea $\mathrm{N}$ concentration in the blood and UN excretion. Blood urea $\mathrm{N}$ may be promising as an indicator of $\mathrm{N}$ capture in the rumen because BUN is positively correlated with ruminal

Table 6. Least squares means for blood metabolites, liver enzyme activity, and blood insulin concentration in dairy calves fed starters differing in corn grain processing methods (ground corn vs. steam-flaked corn) with different starter protein content (18 vs. $21 \%$, DM basis; $\mathrm{n}=12$ calves per treatment)

\begin{tabular}{|c|c|c|c|c|c|c|c|c|}
\hline \multirow[b]{3}{*}{ Item } & \multicolumn{4}{|c|}{ Treatment $^{1}$} & \multirow[b]{3}{*}{ SEM } & \multirow{2}{*}{\multicolumn{3}{|c|}{$P$-value ${ }^{2}$}} \\
\hline & \multicolumn{2}{|c|}{ GRC } & \multicolumn{2}{|c|}{ SFC } & & & & \\
\hline & $18 \mathrm{CP}$ & $21 \mathrm{CP}$ & $18 \mathrm{CP}$ & $21 \mathrm{CP}$ & & Corn & $\mathrm{CP}$ & Corn $\times \mathrm{CP}$ \\
\hline \multicolumn{9}{|c|}{ Glucose (mg/dL) } \\
\hline Preweaning & 94 & 105 & 102 & 108 & 6.15 & 0.55 & 0.36 & 0.70 \\
\hline Postweaning & 82.8 & 78.6 & 88.3 & 95.0 & 3.55 & 0.03 & 0.81 & 0.28 \\
\hline Postweaning & 0.32 & 0.34 & 0.40 & 0.37 & 0.02 & 0.08 & 0.82 & 0.49 \\
\hline \multicolumn{9}{|c|}{ Total protein $(\mathrm{g} / \mathrm{dL})$} \\
\hline Preweaning & 5.97 & 6.23 & 6.20 & 6.10 & 0.13 & 0.81 & 0.67 & 0.35 \\
\hline Postweaning & 6.54 & 6.72 & 6.58 & 6.72 & 0.10 & 0.87 & 0.27 & 0.85 \\
\hline \multicolumn{9}{|l|}{ Albumin (g/dL) } \\
\hline Preweaning & 3.43 & 3.60 & 3.51 & 3.66 & 0.08 & 0.58 & 0.16 & 0.99 \\
\hline Postweaning & 3.50 & 3.83 & 3.76 & 3.72 & 0.09 & 0.57 & 0.28 & 0.17 \\
\hline Postweaning & 71.1 & 74.0 & 71.5 & 57.7 & 4.78 & 0.24 & 0.38 & 0.22 \\
\hline \multicolumn{9}{|c|}{ Alanine aminotransferase (IU/L) } \\
\hline Preweaning & 8.21 & 9.16 & 9.0 & 10.2 & 0.83 & 0.37 & 0.30 & 0.97 \\
\hline Postweaning & 17.4 & 21.5 & 23.1 & 16.6 & 2.65 & 0.91 & 0.75 & 0.17 \\
\hline \multicolumn{9}{|l|}{ Insulin (IU/L) } \\
\hline Preweaning & 6.40 & 7.52 & 8.63 & 10.2 & 0.98 & 0.04 & 0.37 & 0.87 \\
\hline Postweaning & 4.77 & 6.17 & 6.66 & 7.95 & 0.52 & 0.05 & 0.10 & 0.85 \\
\hline
\end{tabular}

${ }^{1}$ Treatments were as follows: starter diet contained ground corn grain with $18 \% \mathrm{CP}$ (GRC-18CP), starter diet contained ground corn grain with 21\% CP (GRC-21CP), starter diet contained steam-flaked corn grain with 18\% CP (SFC-18CP), and starter diet contained steam-flaked corn grain with $21 \% \mathrm{CP}$ (SFC-21CP).

${ }^{2}$ Statistical comparisons: corn $=$ corn grain processing method (ground corn grain vs. steam-flaked corn grain); CP $=18$ vs. $21 \%$ dietary starter protein content based on $\mathrm{DM}$; corn $\times \mathrm{CP}=$ interaction of grain processing method and dietary starter protein content. 
$\mathrm{NH}_{3}-\mathrm{N}$ concentrations (DePeters and Ferguson, 1992). Moreover, a strong linear relationship between BUN and UN excretion was identified in a previous study (Kohn et al., 2005). The decline in ruminal $\mathrm{NH}_{3}-\mathrm{N}$ concentrations along with lower UN content excreted as part of the urine in the SFC diets may reflect greater $\mathrm{N}$ utilization when calves were fed the SFC diets compared with the GRC diets.

Allantoin excretion in urine increased in the $\mathrm{SFC}$ diet (13.3 vs. $15.4 \mathrm{mmol} / \mathrm{d}$ for GRC and SFC diets, respectively). Due to the greater allantoin excretion, total PD excreted through urine and, subsequently, MPS (76.5 vs. $86.8 \mathrm{~g} / \mathrm{d}$ for GRC and SFC diets, respectively) also increased in calves fed the SFC diet. As stated by Casper et al. (1999), the optimum ruminal starch and protein degradation could maximize MPS to support animal growth. In addition to the mechanisms discussed earlier for better ADG and FE in SFC-fed calves, improvement of these variables may be related partially to increased MPS. Accordingly, Theurer et al. (1999) clarified that SFC is highly digestible in the rumen due to the denaturation of the protein matrix of the starch granule. Denaturation of the matrix allows for greater microbial attachment and digestion of the starch granule, increasing the energy available for MPS and consequently increasing utilization of recycled and dietary N. The improved OM and NFC digestibilities found in the SFC diets compared with the GRC diets provided more fermentable substrate for ruminal microbes to increase MPS (Casper et al., 1999). On the other hand, the GRC diets resulted in greater UN excretion rate (16.5 vs. $14.2 \mathrm{~g} / \mathrm{d}$, for GRC and SFC diets, respectively) and a greater UN proportion of total $\mathrm{N}$ intake (34.6\% and $29.0 \%$, for the GRC and SFC diets, respectively). Improvements in $\mathrm{N}$ usage may be related to altered grain starch structure, which becomes more rapidly degradable and allows easier accessibility for ruminal microbes in extensively processed grains compared with simple grinding (Theurer et al., 1999; Zhong et al., 2008). Greater UN could be an indicator of lower $\mathrm{N}$ efficiency in ruminants (Kauffman and St-Pierre, 2001; Kohn et al., 2005). By assessing MPS results obtained in the current trial, and also UN excretion as a proportion of total $\mathrm{N}$ intake, we suggest that inclusion of SFC in the starter diet would be more efficient than GRC from the $\mathrm{N}$ metabolism perspective through improved ruminal $\mathrm{N}$ capture rate and reduced $\mathrm{N}$ wastage as part of the urine. Additional research with more data from urine samples is needed to conclusively evaluate urinary PD excretion, MPS, and N efficiency in dairy calves.

Propionate is the main precursor of glucose in ruminants (Huntington, 1997). Although ruminal pro- portion of propionate was unchanged, greater total digestibility would increase propionate supply, which might be related to the increased glucose concentration during the postweaning period in calves fed the SFC diets. Other gluconeogenic substrates rather than propionate also may influence blood glucose concentrations. Furthermore, processing techniques that manipulate the extent of degradation also increase starch availability in the small intestine (Svihus et al., 2005), which could positively influence blood glucose concentrations (Kazemi-Bonchenari et al., 2017). Increased preweaning blood BHB concentrations in SFC-fed calves is reasonably related to greater ruminal butyrate concentrations of calves fed the SFC diets. Liver enzyme activity (AST and ALT) did not differ across treatments in the current trial, showing a healthy liver function from both processing methods. Blood insulin concentrations increased in calves fed the SFC diets, which could be related to greater blood glucose concentrations or to greater ruminal VFA concentrations, which have been indicated to be a stimulator for insulin secretion in ruminants (Manns et al., 1967). Regardless of the mechanisms involved in insulin secretion in dairy calves, our results agree with previous reports that stated that greater insulin concentration may influence growth performance of growing ruminants (Wester et al., 2000; Kazemi-Bonchenari et al., 2020).

\section{Starter Protein Content}

We tested the recommended amount of $\mathrm{CP}$ based on NRC, 2001 (18\%) versus 21\% CP (DM basis) in the current trial. In accordance with our results, Luchini et al. (1991) reported no difference in the intake of calves fed starters with $18 \%$ and $21 \%$ CP through $84 \mathrm{~d}$ of age. However, in a study where calves were fed with starters containing vast ranges of protein from $15 \%$ up to $22.4 \% \mathrm{CP}$, intake was maximal for calves fed a $19.6 \%$ CP starter (Akayezu et al., 1994). However, Stamey et al. (2012) reported that starter with $25.5 \% \mathrm{CP}$ (DM basis) provided modest benefits in starter intake (particularly around weaning) and growth for dairy calves in an enhanced early nutrition program compared with a conventional starter diet contained $19.6 \%$ CP. Our results suggest that both $18 \%$ and $21 \% \mathrm{CP}$ adequately supplied the protein requirements of animals and did not influence intake in the current experiment. The ADG was in a similar range for $18 \mathrm{CP}$ and $21 \mathrm{CP}$ diets. Accordingly, FE did not differ between the $2 \mathrm{CP}$ contents. In line with our results, increasing starter CP concentration to $20 \%$ or $24 \%$ did not influence calf performance (Daneshvar et al., 2017). Dairy calves were fed with a gradually increased starter CP content (15, 
16.8, 19.6, or 22.4\%, DM basis), and Akayezu et al. (1994) suggested that the optimal amount of CP in calf starters to promote maximum growth of calves from birth to 8 to 12 wk of age is between $16.5 \%$ and $19.5 \%$.

The digestibility of NDF was improved with greater dietary $\mathrm{CP}$ content. Irrespective of the $\mathrm{CP}$ content of the starter diet, this improvement may primarily be related to a lower content of wheat bran in $21 \mathrm{CP}$ diets, which would decrease indigestible NDF and subsequently increased NDF digestibility. In addition, greater protein content supplied through higher soybean meal level in the $21 \mathrm{CP}$ diet, provided more $\mathrm{AA}$, peptides, and elevated BCVFA concentration in the ruminal fluid of calves, which in turn could improve fiber digestibility (Yang, 2002). Greater acetate concentration in ruminal fluid obtained from calves fed the higher CP content in the starter diet may be due to greater fiber digestibility.

Slightly increased BUN concentration in calves fed greater $\mathrm{CP}$ content in their starter diet may be attributed to excess ruminal $\mathrm{N}$ concentration during the postweaning period, perhaps partly due to lower protein requirements of weaned versus preweaning calves (Kazemi-Bonchenari et al., 2018). In addition, during the MPS trial in the postweaning period calves fed $21 \%$ $\mathrm{CP}$ tended to have greater $\mathrm{N}$ intake but it did not affect MPS. This slight increase in $\mathrm{N}$ intake and BUN concentration did not negatively affect $\mathrm{N}$ excreted as a proportion of total $\mathrm{N}$ excretion in urine, demonstrating unchanged $\mathrm{N}$ efficiency in both diets. But in a more extensive difference of $\mathrm{CP}(17.2 \%$ to $21.3 \%$, DM basis), Stobo and Roy (1973) found no improvement in $\mathrm{N}$ retention but less UN excretion in calves fed the lower CP content. It seems that factors such as starter protein content (Luchini et al., 1991; Stamey et al., 2012), starch source (Maiga et al., 1994; Mirzaei et al., 2016), dietary PS (Omidi-Mirzaei et al., 2018), grain processing method (Mojahedi et al., 2018), and even milk feeding method (Daneshvar et al., 2017) could alter $\mathrm{N}$ metabolism in dairy calves.

\section{Interaction of Corn Grain Processing and Starter Protein Content}

Although ADG and FE were influenced by corn processing methods in the current trial, no interaction with starter protein content was found. As a preliminary study, our experiment tested the interaction of corn processing with 2 levels of starter CP content, which were equal to the NRC (2001) recommendation $(18 \%$ $\mathrm{CP})$ or a higher level $(21 \% \mathrm{CP})$. Our results confirm the report by Hill et al. (2007) that the NRC (2001) recommendation for starter protein content is adequate for dairy calf performance. However, we suggest that in the future research should evaluate the effects of corn processing methods over a wider range of starter $\mathrm{CP}$ content.

Regarding the growth indices in the current study, the heights for withers and hip were influenced by the interaction effect of the grain processing method and starter protein content. The greatest withers and hip heights at weaning time and at the end of the experiment were observed for SFC-21CP treatment. This clarifies that high fermentable starch, as well as higher $\mathrm{OM}$ and NFC digestibilities observed in the SFC diets concurrent with greater $\mathrm{N}$ availability in the $21 \mathrm{CP}$ diet, has the potential to positively influence animal growth. Because we observed no interaction effect for ruminal metabolism or MPS in the current trial, this interaction may have resulted through a synergistic effect of greater energy provided through the SFC diet (Theurer et al., 1999) and greater AA provided with higher protein content in starter diet into the small intestine (Luchini et al., 1991; Akayezu et al., 1994). The greater blood glucose concentration for dairy calves fed the SFC diets could have a sparing effect on AA and divert them into greater structural growth instead of entering into the gluconeogenesis pathway (Young, 1977). Therefore, calves fed the SFC diets along with the $21 \mathrm{CP}$ diet seem to have greater AA available for growth. Regardless of the mechanism of improved withers and hip heights by feeding the SFC-21CP treatment in the current trial, the importance of withers height of female calves under 6 mo of age on future production traits after first calving (Kertz et al., 1998) and the relationship between hip height and production traits in dairy cows (Shanks and Spahr, 1982) have been documented. Furthermore, Heinrichs and Hargrove (1987) observed that the correlation between withers height of heifers measured between 1 and 24 mo of age and first-lactation milk yield (0.41) was greater than that of BW (0.34). Van De Stroet et al. (2016) observed that dairy heifer calves that were shorter had the lowest milk production potential and were the least likely to remain in the herd until the first lactation.

\section{CONCLUSIONS}

Our results show that steam flaking of corn grain increased the ADG, FE, ruminal VFA, the molar proportion of propionate and butyrate in the rumen, and the digestibility of OM and NFC compared with grinding corn grain in dairy calves. Moreover, the SFC diets improved $\mathrm{N}$ efficiency by improving MPS and reducing UN excretion. Increasing the CP content of starter diets from $18 \%$ to $21 \%$ did not affect the calf performance but improved the digestibility of NDF. We found that 
the combination of $\mathrm{CP}$ contents and corn grain processing in starter diets did not have an effect on most indicators of intake, growth performance, digestibility, and blood metabolites. However, the inclusion of SFC and $21 \% \mathrm{CP}$ in the starter improved the heights of withers and hip of dairy calves. In conclusion, irrespective of the marginal benefit obtained in SFC-21CP treatment for the height of calves in the current experiment, $18 \%$ $\mathrm{CP}$ content in starter diet also could be used efficiently when calves are fed diets containing SFC.

\section{ACKNOWLEDGMENTS}

Great appreciation is extended to M. A. Moshayedi, manager in chief, and A. Sadeghi-Sharif, technical manager of the Zarrin-Khoosheh commercial dairy farm, as well as its helpful staff, for their cooperation in conducting the study. Great thanks to M. Namdari (calf rearing technician) for valuable help throughout the experiment. Thanks to A. Mirjafari, S. Avakh, M. Rastgoo, M. Mashayekhi, from Arak University, for their help in urine sampling times in this experiment. The authors have no conflicts of interest to declare.

\section{REFERENCES}

Abdelgadir, I. E. O., J. L. Morrill, and J. J. Higgins. 1996. Ruminal availabilities of protein and starch: Effects on growth and ruminal and plasma metabolites of dairy calves. J. Dairy Sci. 79:283-290. https://doi.org/10.3168/jds.S0022-0302(96)76362-2.

Ahmadi, F., G. R. Ghorbani, A. Sadeghi-Sefidmazgi, M. Heydari, H. Rafiee, and K. A. Beauchemin. 2020. Performance and feeding behavior of dairy cows fed high-concentrate diets containing steam-flaked or ground corn varying in particle size. J. Dairy Sci. 103:3191-3203. https://doi.org/10.3168/jds.2019-17344.

Akayezu, J. M., J. G. Linn, D. E. Otterby, W. P. Hansen, and D. G. Johnson. 1994. Evaluation of calf starters containing different amounts of crude protein for growth of Holstein calves. J. Dairy Sci. 77:1882-1889. https://doi.org/10.3168/jds.S0022 -0302(94)77130-7.

Annison, E. F., and D. G. Armstrong. 1970. Volatile fatty acid metabolism and energy supply. Pages 422-437 in Physiology and Digestion and Metabolism in Ruminants. A. T. Phillipson, ed. Newcastle upon Tyne, UK.

AOAC International. 2002. Official Methods of Analysis. 17th ed. AOAC International, Arlington, VA.

Aragona, K. M., F. X. Suarez-Mena, T. S. Dennis, J. D. Quigley, W. Hu, T. M. Hill, and R. L. Schlotterbeck. 2020. Effect of starter form, starch concentration, and amount of forage fed on Holstein calf growth from 2 to 4 months of age. J. Dairy Sci. 103:2324-2332. https://doi.org/10.3168/jds.2019-17474.

ASAE (American Society of Agricultural Engineers). 1995. Method of determining and expressing fineness of feed material by sieving. Page 461 in ASAE Standards 1995. ASAE, St. Joseph, MI.

Bateman, H. G. II, T. M. Hill, J. M. Aldrich, and R. L. Schlotterbeck. 2009. Effects of corn processing, particle size, and diet form on performance of calves in bedded pens. J. Dairy Sci. 92:782-789. https://doi.org/10.3168/jds.2008-1242.

Bergman, E. N. 1990. Energy contributions of volatile fatty acids from the gastrointestinal tract in various species. Physiol. Rev. 70:567590. https://doi.org/10.1152/physrev.1990.70.2.567.
Broderick, G. A., and J. H. Kang. 1980. Automated simultaneous determination of ammonia and total amino acids in ruminal fluid and in vitro media. J. Dairy Sci. 63:64-75. https://doi.org/10 .3168/jds.S0022-0302(80)82888-8.

Casper, D. P., H. A. Maiga, M. J. Brouk, and D. J. Schingoethe. 1999. Synchronization of carbohydrate and protein sources on fermentation and passage rates in dairy cows. J. Dairy Sci. 82:1779-1790. https://doi.org/10.3168/jds.S0022-0302(99)75408-1.

Chen, X. B., and M. J. Gomes. 1992. Estimation of microbial protein supply to sheep and cattle based on urinary excretion of purine derivatives: An overview of technical details. International Feed Research Unit, Occasional Publ. Rowett Research Institute, Aberdeen, United Kingdom.

Clark, J. H., T. H. Klusmeyer, and M. R. Cameron. 1992. Microbial protein synthesis and flows of nitrogen fractions to the duodenum of dairy cows. J. Dairy Sci. 75:2304-2323. https://doi.org/10 .3168/jds.S0022-0302(92)77992-2.

Corona, L., S. Rodriguez, R. A. Ware, and R. A. Zinn. 2005. Comparative effects of whole, ground, dry-rolled, and steam-flaked corn on digestion and growth performance in feedlot cattle. Prof. Anim. Sci. 21:200-206. https://doi.org/10.15232/S1080-7446(15)31203-1.

Daneshvar, D., M. Khorvash, E. Ghasemi, and A. H. Mahdavi. 2017. Combination effects of milk feeding methods and starter crude protein concentration: Evaluation on performance and health of Holstein male calves. Anim. Feed Sci. Technol. 223:1-12. https:// doi.org/10.1016/j.anifeedsci.2016.10.025.

Dennis, T. S., F. X. Suarez-Mena, T. M. Hill, J. D. Quigley, and R. L. Schlotterbeck. 2017. Effects of egg yolk inclusion, milk replacer feeding rate, and low-starch (pelleted) or high-starch (texturized) starter on Holstein calf performance through 4 months of age. J. Dairy Sci. 100:8995-9006. https://doi.org/10.3168/jds.2017-13169.

Dennis, T. S., F. X. Suarez-Mena, T. M. Hill, J. D. Quigley, R. L. Schlotterbeck, and G. J. Lascano. 2018. Short communication: Effect of replacing corn with beet pulp in a high concentrate diet fed to weaned Holstein calves on diet digestibility and growth. J. Dairy Sci. 101:408-412. https://doi.org/10.3168/jds.2017-13292.

DePeters, E. J., and J. D. Ferguson. 1992. Nonprotein nitrogen and protein distribution in the milk of cows. J. Dairy Sci. 75:31923209. https://doi.org/10.3168/jds.S0022-0302(92)78085-0.

Gimeno, A., A. Al Alami, L. Abecia, A. de Vega, M. Fondevila, and C. Castrillo. 2015. Effect of type (barley vs. maize) and processing (grinding vs. dry rolling) of cereal on ruminal fermentation and microbiota of beef calves during the early fattening period. Anim. Feed Sci. Technol. 199:113-126. https://doi.org/10.1016/j .anifeedsci.2014.11.008.

Gonzalez-Ronquillo, M., J. Balcells, J. A. Guada, and F. Vicente. 2003. Purine derivative excretion in dairy cows: Endogenous excretion and the effect of exogenous nucleic acid supply. J. Dairy Sci. 86:1282-1291. https://doi.org/10.3168/jds.S0022-0302(03)73712 $-6$.

Heinrichs, A. J., and G. L. Hargrove. 1987. Standards of weight and height for Holstein heifers. J. Dairy Sci. 70:653-660. https://doi .org/10.3168/jds.S0022-0302(87)80055-3.

Heinrichs, A. J., C. M. Jones, L. R. Van Roekel, and M. A. Fowler. 2003. Calf Track: A system of dairy calf workforce management, training, and evaluation and health evaluation. J. Dairy Sci. 86(Suppl. 1):115-123.

Hill, T. M. J. M., P. A. S. Aldrich, R. L. Schlotterbeck, and H. G. Bateman II.. 2007. Protein concentrations for starters fed to transported neonatal calves. Prof. Anim. Sci. 23:123-134. https://doi .org/10.15232/S1080-7446(15)30952-9.

Huntington, G. B. 1997. Starch utilization by ruminants: From basics to the bunk. J. Anim. Sci. 75:852-867. https://doi.org/10.2527/ 1997.753852x.

Iranian Council of Animal Care. 1995. Guide to the care and use of experimental animals, Vol. 1. Isfahan University of Technology, Isfahan, Iran.

Kauffman, A. J., and N. R. St-Pierre. 2001. The relationship of milk urea nitrogen to urine nitrogen excretion in Holstein and Jersey 
cows. J. Dairy Sci. 84:2284-2294. https://doi.org/10.3168/jds S0022-0302(01)74675-9.

Kazemi-Bonchenari, M., M. Dehghan-Banadaky, F. Fattahnia, A. Saleh-Bahmanpour, M. Jahani-Moghadam, and M. Mirzaei. 2020. Effects of linseed oil and rumen-undegradable protein: rumen-degradable protein ratio on performance of Holstein dairy calves. Br. J. Nutr. 123:1247-1257. https://doi.org/10.1017/ S0007114520000586.

Kazemi-Bonchenari, M., R. Falahati, M. Poorhamdollah, S. R. Heidari, and A. Pezeshki. 2018. Essential oils improved weight gain, growth and feed efficiency of young dairy calves fed 18 or $20 \%$ crude protein starter diets. J. Anim. Physiol. Anim. Nutr. (Berl.) 102:652661. https://doi.org/10.1111/jpn.12867.

Kazemi-Bonchenari, M., M. Mirzaei, M. Jahani-Moghadam, A. Soltani, E. Mahjoubi, and R. A. Patton. 2016. Interactions between levels of heat-treated soybean meal and prilled fat on growth, rumen fermentation, and blood metabolites of Holstein calves. J. Anim. Sci. 94:4267-4275. https://doi.org/10.2527/jas.2016-0514.

Kazemi-Bonchenari, M., A. Z. M. Salem, and S. Lopez. 2017. Influence of barley grain particle size and treatment with citric acid on digestibility, ruminal fermentation and microbial protein synthesis in Holstein calves. Animal 11:1295-1302. https://doi.org/10.1017/ S1751731116002810.

Kertz, A. F., A. Barton, and F. Reutzel. 1998. Relative efficiencies of wither height and body weight increase from birth until first calving in Holstein cattle. J. Dairy Sci. 81:1479-1482. https://doi.org/ 10.3168/jds.S0022-0302(98)75712-1.

Khan, M. A., H. J. Lee, W. S. Lee, H. S. Kim, K. S. Ki, T. Y. Hur, G. H. Suh, S. J. Kang, and Y. J. Choi. 2007. Structural growth, rumen development, and metabolic and immune responses of Holstein male calves fed milk through step-down and conventional methods. J. Dairy Sci. 90:3376-3387. https://doi.org/10.3168/jds .2007-0104

Khan, M. A., H. J. Lee, W. S. Lee, H. S. Kim, S. B. Kim, S. B. Park, K. S. Baek, J. K. Ha, and Y. J. Choi. 2008. Starch source evaluation in calf starter: II. Ruminal parameters, rumen development, nutrient digestibilities, and nitrogen utilization in Holstein calves. J. Dairy Sci. 91:1140-1149. https://doi.org/10.3168/jds.2007-0337.

Kohn, R. A., M. M. Dinneen, and E. Russek-Cohen. 2005. Using blood urea nitrogen to predict nitrogen excretion and efficiency of nitrogen utilization in cattle, sheep, goats, horses, pigs, and rats. J. Anim. Sci. 83:879-889. https://doi.org/10.2527/2005.834879x.

Luchini, N. D., S. F. Lane, and D. K. Combs. 1991. Evaluation of starter crude protein level and feeding regime for calves weaned at 26 days of age. J. Dairy Sci. 74:3949-3955. https://doi.org/10 .3168/jds.S0022-0302(91)78589-5.

Maiga, H. A., D. J. Schingoethe, F. C. Luden, W. L. Tucker, and D. P. Casper. 1994. Response of calves to diets that varied in amounts of ruminally degradable carbohydrate and protein. J. Dairy Sci. 77:278-283. https://doi.org/10.3168/jds.S0022-0302(94)76952-6.

Manns, J. G., J. M. Boda, and R. F. Willes. 1967. Probable role of propionate and butyrate in control of insulin secretion in sheep. Am. J. Physiol. 212:756-764. https://doi.org/10.1152/ajplegacy .1967 .212 .4 .756 .

Mirzaei, M., M. Khorvash, G. R. Ghorbani, M. Kazemi-Bonchenari, A. Riasi, A. Soltani, B. Moshiri, and M. H. Ghaffari. 2016. Interactions between the physical form of starter (mashed versus textured) and corn silage provision on performance, rumen fermentation, and structural growth of Holstein calves. J. Anim. Sci. 94:678-686. https://doi.org/10.2527/jas.2015-9670.

Mojahedi, S., M. Khorvash, G. R. Ghorbani, E. Ghasemi, M. Mirzaei, and F. Hashemzadeh-Cigari. 2018. Performance, nutritional behavior, and metabolic responses of calves supplemented with forage depend on starch fermentability. J. Dairy Sci. 101:7061-7072. https://doi.org/10.3168/jds.2017-13798.

Murphy, T. A., F. L. Fluharty, and S. C. Loerch. 1994. The influence of intake level and corn processing on digestibility and ruminal metabolism in steers fed all-concentrate diets. J. Anim. Sci. 72:1608-1615. https://doi.org/10.2527/1994.7261608x.
NRC. 2001. Nutrient Requirements of Dairy Cattle. 7th rev. ed. National Academy Press, Washington, DC.

Omidi-Mirzaei, H., A. Azarfar, A. Kiani, M. Mirzaei, and M. H. Ghaffari. 2018. Interaction between the physical forms of starter and forage source on growth performance and blood metabolites of Holstein dairy calves. J. Dairy Sci. 101:6074-6084. https://doi .org/10.3168/jds.2017-13892.

Owens, F. N., D. S. Secrist, W. J. Hill, and D. R. Gill. 1997. The effect of grain source and grain processing on performance of feedlot cattle: A review. J. Anim. Sci. 75:868-879. https://doi.org/10 $.2527 / 1997.753868 \mathrm{x}$.

Philippeau, C., C. Martin, and B. Michalet-Doreau. 1999. Influence of grain source on ruminal characteristics and rate, site, and extent of digestion in beef steers. J. Anim. Sci. 77:1587-1596. https://doi .org/10.2527/1999.7761587x.

Plascencia, A., and R. A. Zinn. 1996. Influence of flake density on the feeding value of steam-processed corn in diets for lactating cows. J. Anim. Sci. 74:310-316. https://doi.org/10.2527/1996.742310x.

Porter, J. C., R. G. Warner, and A. F. Kertz. 2007. Effect of fibre level and physical form of starter on growth and development of dairy calves fed no forage. Prof. Anim. Sci. 23:395-400. https://doi.org/ 10.15232/S1080-7446(15)30994-3.

Quigley, J. D., T. M. Hill, T. S. Dennis, F. X. Suarez-Mena, and R. L. Schlotterbeck. 2018. Effects of feeding milk replacer at 2 rates with pelleted, low-starch or texturized, high-starch starters on calf performance and digestion. J. Dairy Sci. 101:5937-5948. https:// doi.org/10.3168/jds.2017-13851.

Quigley, J. D., T. M. Hill, L. E. Hulbert, T. S. Dennis, F. X. SuarezMena, and E. M. Bortoluzzi. 2019. Effects of fatty acids and calf starter form on intake, growth, digestion, and selected blood metabolites in male calves from 0 to 4 months of age. J. Dairy Sci 102:8074-8091. https://doi.org/10.3168/jds.2019-16688.

Rafiee-Yarandi, H., M. Alikhani, G. R. Ghorbani, M. Heydari, and P. Rezamand. 2019. Dietary protein level and corn processing method: Lactation performance, milk fatty acid composition, rumen and blood parameters of lactation dairy cows. Livest. Sci 221:95-104. https://doi.org/10.1016/j.livsci.2019.01.019.

Savari, M., M. Khorvash, H. Amanlou, G. R. Ghorbani, E. Ghasemi, and M. Mirzaei. 2018. Effects of rumen-degradable protein: rumen-undegradable protein ratio and corn processing on production performance, nitrogen efficiency, and feeding behavior of Holstein dairy cows. J. Dairy Sci. 101:1111-1122. https://doi.org/10.3168/ jds.2017-12776.

Shanks, R. D., and S. L. Spahr. 1982. Relationships among udder depth, hip height, hip width, and daily milk production in Holstein cows. J. Dairy Sci. 65:1771-1775. https://doi.org/10.3168/ jds.S0022-0302(82)82415-6.

Stamey, J. A., N. A. Janovick, A. F. Kertz, and J. K. Drackley. 2012. Influence of starter protein content on growth of dairy calves in an enhanced early nutrition program. J. Dairy Sci. 95:3327-3336. https://doi.org/10.3168/jds.2011-5107.

Stobo, I. J. F., and J. H. B. Roy. 1973. The protein nutrition of the ruminant calf. 4 . Nitrogen balance studies on rapidly growing calves given diets of different protein content. Br. J. Nutr. 30:113-125. https://doi.org/10.1079/BJN19730013.

Svihus, B., A. K. Uhlen, and O. M. Harstad. 2005. Effect of starch granule structure, associated components and processing on nutritive value of cereal starch: A review. Anim. Feed Sci. Technol. 122:303-320. https://doi.org/10.1016/j.anifeedsci.2005.02.025.

Theurer, C. B., J. T. Huber, A. Delgado-Elorduy, and R. Wanderley. 1999. Invited Review: Summary of steam-flaking corn or sorghum grain for lactating dairy cows. J. Dairy Sci. 82:1950-1959. https:/ /doi.org/10.3168/jds.S0022-0302(99)75431-7.

Valadares, R. F. D., G. A. Broderick, S. S. Valadares Filho, and M. K. Clayton. 1999. Effect of replacing alfalfa silage with high moisture corn on ruminal protein synthesis estimated from excretion of total purine derivatives. J. Dairy Sci. 82:2686-2696. https://doi.org/10 .3168/jds.S0022-0302(99)75525-6.

Van De Stroet, D. L., J. A. Calderón Díaz, K. J. Stalder, A. J. Heinrichs, and C. D. Dechow. 2016. Association of calf growth traits 
with production characteristics in dairy cattle. J. Dairy Sci. 99:8347-8355. https://doi.org/10.3168/jds.2015-10738.

Van Keulen, J., and B. A. Young. 1977. Acid insoluble ash as a natural marker for digestibility studies. J. Dairy Sci. 44:282-287.

Van Soest, P. J., J. B. Robertson, and B. A. Lewis. 1991. Methods of dietary fiber, neutral detergent fibre and non-starch polysaccharides in relation to animal nutrition. J. Dairy Sci. 74:3583-3597. https://doi.org/10.3168/jds.S0022-0302(91)78551-2.

Wester, T. J., G. E. Lobley, L. M. Birnie, and M. A. Lomax. 2000. Insulin stimulates phenelalanine uptake across the hind limb in fed lambs. J. Nutr. 130:608-611. https://doi.org/10.1093/jn/130 .3.608.

Yang, C. M. J. 2002. Response of forage fibre degradation by ruminal microorganisms to branched-chain volatile fatty acids, amino acids, and dipeptides. J. Dairy Sci. 85:1183-1190. https://doi.org/10 .3168/jds.S0022-0302(02)74181-7.
Young, J. W. 1977. Gluconeogenesis in cattle: Significance and methodology. J. Dairy Sci. 60:1-15. https://doi.org/10.3168/jds.S0022 $-0302(77) 83821-6$

Zhong, R. Z., J. Li, Y. Gao, Z. Tan, and G. Ren. 2008. Effects of substitution of different levels of steam-flaked corn for finely ground corn on lactation and digestion in early lactation dairy cows. J. Dairy Sci. 91:3931-3937. https://doi.org/10.3168/jds.2007-0957.

Zinn, R. A., E. G. Alvarez, M. F. Montano, A. Plascencia, and J. E. Ramirez. 1998. Influence of tempering on the feeding value of rolled corn in finishing diets for feedlot cattle. J. Anim. Sci. 76:2239-2246. https://doi.org/10.2527/1998.7692239x.

Zinn, R. A., F. N. Owens, and R. A. Ware. 2002. Flaking corn: Processing mechanics, quality standards, and impacts on energy availability and performance of feedlot cattle. J. Anim. Sci. 80:11451156. https://doi.org/10.2527/2002.8051145x. 